\title{
Psychopharmacology: Finding One's Way
}

Joel Elkes, M.D.

The paper recalls the experiences of the author over the past forty-eight years in a field which later became known as psychopharmacology. The author began in physical chemistry and traditional pharmacology. His interest in the nervous system stemmed from $X$-ray diffraction studies on the structure of living myelin, and led, by way of studies on the distribution of cholinesterases and the effects of atropine, to the study of the effects of drugs on the electrical activity of the brain in the conscious animal. At the clinical level it included studies of the effects of drugs on catatonic schizophrenic stupor. These studies took place before the discovery of chlorpromazine. They led to the creation, in 1951, of the Department of Experimental Psychiatry in Birmingham, England, the first department of its kind in the world. The department included neurochemical, electrophysiological, and animal behavior laboratories and a strong clinical facility (the Uffculme Clinic). The first blind trial of chlorpromazine was carried out in that department in 1953 and 1954. The existence of families of neuroregulatory compounds, having uneven distribution in the brain, and exerting regional chemical field effects in relation to function was postulated on the basis of experimental and clinical findings. The work of colleagues and participants in the various studies is gratefully acknowledged in the text. In 1954 the author served as convening executive secretary of the first International Symposium on Neurochemistry at Oxford, England, the first meeting of its kind. He came to the United States in 1957 and founded, and served as first director of, the new Clinical Neuropharmacology Research Center, now the Center for Neuroscience at St. Elizabeth's Hospital, Washington, DC. He directed this program from 1957 to 1963. Subsequent activities at Johns Hopkins, the World Health Organization, and the International Brain Research Organization (IBRO) are recalled. In 1961 he was elected first president of the American College of

Neuropsychopharmacology. In looking back, he notes the sparse and personal nature of the field in the late 1940s and early 1950s, its explosive growth in the wake of the major clinical discoveries, and above all, the emergence of a new science through the interaction of neurochemistry, electrophysiology, studies of animal behavior, and the refinement of the clinical trial. He regards the emergence of concepts of regional chemistry of the brain as particularly significant, and feels that psychopharmacology is ideally positioned to act as an intermediary between classical pharmacology and quantum biology. The transdisciplinary nature of psychopharmacology provides a template for a comprehensive psychiatry of the future-a discipline which is now positioned to lead. He also feels that future discoveries in psychopharmacology will pose a most poignant ethical dilemma for medicine, and argues for a timely readying for these responsibilities. INeuropsychopharmacology 12:93111, 1995]
From the Fetzer Institute, Kalamazoo, Michigan

Address correspondence to Joel Elkes, M.D., Senior Scholar-inResidence, the Fetzer Institute, 9292 WKL Ave, Kalamazoo, MI 49009.

Received December 30, 1992; revised July 1993; accepted September 17, 1993.

Presented at the 1992 ACNP Annual Meeting, held in San Juan, Puerto Rico, December 1992.
KEY WORDS: Psychopharmacology, history; X-ray diffraction, myelin; Regional neurochemistry; Brain electrical activity in conscious animal; Families of Neuroregulatory compounds; Catatonic stupor; Chlorpromazine; Experimental psychiatry; St. Elizabeth's; Johns Hopkins; American College of Neuropsychopharmacology (ACNP); World Health Organization (WHO); International Brain Research Organization (IBRO) 
I am much honored to be part of this illustrious series. In their distinguished contributions that preceded my own, Drs. Frank Ayd (1991) and Heinz Lehman (1991) have given us - each in their own idiom - a fine account of how our field and our college came to be. So when Dr. Oakley Ray intimated that I was to follow them, I asked him - a little hesitatingly - what I should talk about. "Your times, and how you found your way," said he. By the time I left his office, I had my title: "Finding One's Way" is what this talk is about; though, on reflection, "Trial and Error" might have been even more appropriate.

Personal beginnings are hard to trace; they appear most clearly in retrospect. My entry into psychopharmacology was far from direct. It happened in the midforties through a fortunate play of synchronicities. Let me explain.

Physics and the mind have been with me since my youth, but physics came first. At high school, I had three heroes: Einstein, Ehrlich, and Goethe. I spent my first prize monies on accounts of the new physics. To this day, I recall the awe with which I viewed cloud chamber photographs that rendered visible the mysterious geometry of particle paths in collision. As a novice (I had no mathematical training beyond calculus) I could not go beyond first principles. And yet, as I read myself into the field (French 1979); as I tried to grasp the curious transforms, jumps, symmetries, and asymmetries operating in particle physics, I kept on imagining the life of the mind as a molecular process, linking it in some way to particle physics. It was, of course, a fatuous exercise; yet, it gave me strange satisfaction to engage in such molecular games. Much, much later, I came upon Pauling's concepts of the "hydrogen bond" (Pauling 1945). I still recall the thrill of the first reading, like discovering a new and profound piece of music.

Quite early, thus, I began to think of molecules visually; and when my father, a prominent physician, directed me to Paul Ehrlich's writings (Himmelweit 1956), that interest quickened apace. His concept of receptors, accompanied by his famous "lock and key" diagram, implied stereochemical "fit." Ehrlich wrote on the elective affinities of dyes for tissues and bacteria; he had a consuming curiosity about the molecular basis of immunological memory. He also envisioned the fashioning (in our day we would say, "engineering") of drugs that would selectively attack themselves to specific receptors. Tissues could learn, and rational chemotherapy, to him, was an elaborate imitation of nature.

Why Goethe? I cannot truly account for Goethe's lifelong influence on me, except to say that, with Thomas Jefferson, he represents to me the most comprehensive and comprehending of men. The Germans refer to such people as "eine natur," a magnificent phenomenon on nature. There is also another term - "naturforscher" - a searcher of nature. Goethe's life was a continuous conversation between the Without and Within (Nevinson 1931). He cultivated an inner awareness that was never allowed to interfere with the affairs of the world: (He was statesman, counselor, war correspondent). Long before Freud, he befriended his unconscious; and from that teeming laboratory, sent his images out into the world. Man, to him, was a piece of nature that he tried to map and comprehend. There was another dialectic. Alongside poetry, there was science, and even the titles of some of his novels, such as Elective Affinities, reflect this dialectic. His studies in physics (color theory and crystals), botany, and paleontology were fed by the same joyous energy that permeates his conversations and correspondence. Many of his conclusions were wrong. Yet one continues to marvel at his leaps, and his insights. Goethe was a seeker and a seer. Long before concepts of homeostasis and biofeedback, information flow and self regulation, he was a systems man to his marrow. I believe he would have been very intrigued by psychopharmacology.

These three patron saints were at my side as I entered the portals of St. Mary's Hospital Medical School, University of London, where, in retrospect, I was extraordinarily fortunate. I was taught bacteriology by Alexander Fleming (penicillin) and medicine by Charles Wilson (later Lord Moran, Churchill's physician). Sir Almroth Wright, the great immunologist, gave a few select tutorials. Most importantly, I was appointed Student Demonstrator in Physiology by my erstwhile beloved chief, Alastair Frazer. My co-demonstrator was Geoffrey Harris (who later mapped the hypothalamicpituitary axis and became one of the fathers of modern neuroendocrinology.) Martin Roth (later Sir Martin, Founding President of the Royal College of Psychiatry) was a fellow student. Early (and as part of my duties) I read Sir Charles Sherrington's Integrative Action (1911) and to this day feel the impact of Sherrington's concepts of integration as the ordered, reciprocal play of selective excitation and inhibition. Later, I attended, by invitation (and hiding safely in the dark of a back seat), a meeting of the august British Physiological Society, at which Dr. Adrian (later Lord Adrian) demonstrated the firing of neurons. The loudspeaker crackled as he touched a cat's single vibrissa; it remained silent as he touched another. These two events - the reading of Sherrington, and witnessing an emergent neurophysiology - firmly implanted themselves in my mind, and made me determined to get into the nervous system, come what may. Much later, I read a quotation from Sherrington (1941) that proved prophetic:

The body of a worm and the face of a man alike have to be taken as chemical responses. The alchemist dreamed of old that it might be so. The dream, however, supposed a magic chemistry. There they were wrong. The chemis- 
try is plain everyday chemistry. But it is complex. Further, the chemical brew in preparation for it time has been stirring unceasingly throughout some millions of years in the service of a final cause. The brew is a selected brew.

I had to await my turn to get within reach of the "brew." My chief, Alastair Frazer, proposed that I put my interest in physical chemistry to use. His field was not the nervous system, but fat absorption, and he suggested that I work on the structure of the surface coating of the chylomicron, a physiologically present fatty particle that floods the circulation from the thoracic duct after a fatty meal. The envelope was a lipoprotein, and carried a pH-sensitive ionic charge. I developed microelectrophoretic cell and various flocculation techniques as means of characterizing the nature of this lipoprotein coating (Elkes et al. 1939).

I suppose what intrigued me then (and still intrigues me) was inferring the properties of a macromolecular structure from physicochemical measurements, building up a mental picture of the basis of collateral evidence. This wish to visualize, to have a map, often a wrong map, has stayed with me all my life. Playing with macromolecular configurations, fitting models together, became quite a hobby with me and my friends. In any event, with chylomicron, and with its lipoprotein envelope, my quest into the interface between physical chemistry and biology began. I started to read widely, pulled, I supposed, by a wish to penetrate the fundamental building blocks of life; I also ventured into surface chemistry, and the spreading and study of the monomolecular films. It was, of course, the pursuit of an illusion; but even then, the sense of pattern, of configuration, and the effects of subtle variations of an arrangement and charge distribution on a molecule's physicochemical properties became a game that whiled away some idle hours in medical school.

In 1941, Alastair Frazer invited me to join him in starting a Department of Pharmacology in Birmingham, England. Birmingham, even then, had the makings of the great university that it has since become. For one thing, it had a splendid campus, all compact. Within five minutes' walk of the medical school there were the basic science departments: there were giants in physics (Peierls and Oliphant), chemistry (Haworth), statistics (Hogben), genetics (Medawar), and anatomy, and science policy (Zuckerman). Conversation at lunch was propitious and soon turned to the structure of biological membranes and, of course, to lipoproteins. The structure of liquid crystals - the nature of forces, polar, nonpolar and steric - the bonding that made for their ordered cohesion, continued to excite. I found myself visualizing the architecture of membranes, streaming through special pores like a sodium ion, negotiating various channels and portals, with chains collapsing spring-like as these tiny compartments opened and closed. And then, one day I realized that the nervous system was full of lipoproteins, and that myelin was a highly ordered lipoprotein liquid crystal structure.

I came upon the papers of Francis Schmitt (1935, 1941), who was then at St. Louis. I wrote to him and got back a handsome collection of reprints describing his work on the structure of the myelin sheath. I was fascinated by his diagrams. Here was a highly ordered, aesthetically beautiful arrangement, which fit the facts and which made it possible to envision how bimolecular leaflets were built into a highly specialized structure. Myelin, I thought, could provide a model for understanding the structure of a membrane that was ion sensitive and electrochemically responsive. My friend Alastair Frazer concurred, but I found it hard to convince others. However, one fine thing happened: Bryan Finean walked into my laboratory as my first Ph.D. student.

Bryan Finean had got his degree in chemistry doing crystallography of the traditional kind. Looking at the Schmitt diagrams, we posed an obvious question. Schmitt had worked on dried nerve. Could low-angle $x$-ray diffraction be made to work on a nerve that was irrigated and alive? It did not take long for Bryan to design a cell that would allow us to irrigate the nerve, test its viability, expose a segment of it to changes in moisture, and to solvents (such as alcohol or ether), while at the same time obtaining low-angle $x$-ray diffraction patterns. Within three months or so, we were looking at the first $x$-ray diffraction photograph of living sciatic nerve; I still remember the thrill of seeing that film. To me there was also a profound personal and psychological element in this engagement. I was moving from somebody else's field, fat absorption, and entering the field that mysteriously pulled me, the nervous system, albeit by creeping up the myelin sheath!

Our studies gave us a picture, a sort of basic scaffolding, into which specialized receptors could fit. Cholesterol and phospholipids were accommodated in these diagrams. We also examined the effects of temperature, moisture, alcohol, and ether on myelin structure (Elkes and Finean 1949, 1953a,b). Gradually, in a small circle of physical chemists, and what was then the nucleus of molecular biology in Britain, we made some headway. However, when we demonstrated our findings to the Physiological or the Pharmacological Society, we got very peculiar looks. People were very skeptical of the model value of the myelin for the study of the structure of biological membranes, and only a few stopped by our demonstration stalls. It is significant who they were: Lord Adrian, Sir Henry Dale, J.H. Gaddum, and Alan Hodgkin. They were interested. So was Astbury, father of "biomolecular structure," and Bernal, a great crystallographer and physicist. As Bryan Finean's work was recognized, as he went to MIT, to Caracas, to Stockholm, as he published his mono- 
graphs, including one with Engstrom (Engstrom and Finean 1958; Finean 1961) his views gathered strength. Today, he is a recognized and respected authority in his field, and I am glad for him, and a little proud at having had something to do with his success.

For me, there was also a much more personal satisfaction. I was in the nervous system, yet, as it is apparent, still edging safely at the periphery, a long way from behavior, and the mode of action of psychoactive drugs. However, once again, lucky chance cleared the way.

\section{PHARMACOLOGY AND EXPERIMENTAL PSYCHIATRY IN BIRMINGHAM, ENGLAND}

There was in Birmingham, in the laboratory immediately below the Department of Pharmacology, a small subdepartment of two rooms administered from the Dean's office, called "Mental Diseases Research." In charge of it was a gifted neuropathologist, Dr. F.A. Pickworth, who held the view that mental disease was a capillary disease, and that all disorders were reflected in an abnormal cerebral vascular bed (Pickworth 1941). He had developed beautiful benzidine staining techniques for demonstrating the small cerebral vessels, and the laboratory was filled with innumerable slices and slides of the brain in all manner of pathological states, stained by his methods. This treasury represented Dr. Pickworth's life work.

Dr. Pickworth retired, and again serendipity took me by the hand. For the laboratory reverted to the Department of Pharmacology, and I became administratively responsible for its program. Our Department of Pharmacology was growing by leaps and bounds. When we arrived in Birmingham in 1942, there were two people; when I left, in 1950, there were 42 in the department. I was getting my taste for administration and helping people to perform. While Bryan Finean and I were busy with our studies, another event took place. The war had ended. Our military intelligence had given us insights into the secret German chemical warfare work, and particularly the anticholinesterases and their tremendous specificity for certain enzymes in the brain. We were asked to work with the anticholinesterases: DFP, TEPP, and the like. We started mapping the cholinesterases in various areas of the brain; inhibiting the "true" and "pseudo" enzymes from birth; observing the effect of such inhibition on the emergence of various inborn reflexes (Elkes and Todrick 1955). It was a long, long way from fat absorption, and some way from lipoproteins. But, at long last, it was the brain, it was drugs; and I was even beginning to "smell" that mysterious entity called behavior. In those days, there were few texts on neurochemistry. There was Irvine Page's seminal book (1937); there were Quastel's papers
(Michaelis and Quastel 1941); there were Harold Himwich's (Himwich et al. 1940), and Derek Richter's early contributions (1940); and there was, of course, always Thudichum (1884). I also started reading Masserman (1946) and McDougall (1935), in the hope of linking chemistry to behavior. And then there appeared, in 1948, Feldberg and Vogt's classical paper in the Journal of Physiology (1948) questioning the universal role of acetylcholine in the central nervous system.

In retrospect, it becomes apparent to me that I was once again approaching my central interest, gingerly and carefully, as if I were defusing a bomb. For it is plain that what attracted me to research in psychiatry was an urge to leave the bench and get to people; and what made me circumambulate this purpose was my feeling of safety with things. Somehow, mental disease research, or "experimental psychiatry" (as I was beginning to call it in my mind), presented a sort of compromise. It led inevitably to human work, but it did so by way of experiment and control. This double bookkeeping worked for a time, for an astonishingly long time; it took a further five years to break through the barrier.

As we were feeling our way through the distribution of the cholinesterases, I began to read on the psychoactive drugs. The furst required dissection in the cold room and mapping of the enzymes in various parts of the brain by a succession of extraction elution, incubation and bioassay, a tedious approach to regional neurochemistry: the second involved human studies. Kluver's papers on mescaline (1942) proved an illumination. Here was an extraordinary range of observations, with profound implications for a chemical pathophysiology of the psychoses. By accident, too, I came across descriptions of the somatic and psychologic accompaniments of catatonic stupor, and saw some patients exhibiting this syndrome in the local mental hospital. At that time, Jean Delay came over to London (this was before the discovery of chlorpromazine). It was his first contact across the Channel since the war, and he told us of his experiments of the effects of amytal in catatonic stupor. (I was not aware of Lindemann's work [Lindemann and Malamud 1934] at that time.) Shorvon was developing his ether abreactive techniques (Sargant and Shorvon 1945). It was not long before we decided to embark on a study of the effects of drugs on catatonic stupor and began to look for clinical material. I obtained a small grant for this work from the hospital research fund and advertised for a research associate. No response was forthcoming, but one evening, when I was despondently telling Charmian, my former wife (who was in general practice at the time), about the lack of appeal for a job of this kind, another of those taps of fate took place. For quietly she asked me whether I had thought of her in this context. I said that I honestly 
hadn't and was delighted at her interest. She weighed things very carefully, finally deciding that she would give the job a try.

We began to work at the Winson Green Mental Hospital (The Birmingham City Mental Hospital, now all Saints Hospital), whose superintendent, J.J. O'Reilly, proved a real friend. He put a small research room at our disposal and allowed us to choose patients using our criteria; he also gave us nursing help. Thus, our catatonia study developed. We used homemade gadgetry to measure muscle "tone" and foot temperature and developed our own rating scales to measure change. The study taught us the enormous value of working in a realistic mental hospital setting. We communicated the results first to the Pharmacological Society of Great Britain, and then, some years later, to psychiatric groups (Elkes 1957). They created a good deal of attention. Amytal, administered in full hypnotic doses intravenously, led to a paradoxical awakening of patients in catatonic stupor, a relaxation of muscle tone, and rise in foot temperature. The effect of amphetamine was equally paradoxical. It led to a deepening of the stupor, increase in muscle rigidity, and deepening cyanosis. We also tried mephenesin, which had been shown by Frank Berger (Berger and Bradley 1946) to be a powerful spinal internuncial neuron blocking agent, and through his prescient insights, later led to meprobamate, and a whole family of anxiolytics. When tested in catatonic schizophrenic stupor, mephenesin produced marked muscle relaxation. There was, however, little effect on psychomotor response or peripheral temperature. We also studied the ability of patients to draw - for ten minutes, without promptingwhile under the influence of drugs. Amytal markedly increased this ability, and amphetamine inhibited it. The experiments thus suggested selectivity in the action of drugs on catatonic stupor, and raised the question of the relation of hyperarousal to catatonic withdrawal. Most important, however, these experiments established - at a tangible, as well as a conceptual level-the need of working in parallel. The laboratory and the ward became ends of a continuum of related activities.

It was then, I suppose, that I decided that experimental psychiatry was clinical, or that it was nothing. Let it draw on the bench sciences, let it look for neural correlates of behavior in the animal model, let it delve deeply into processes governing the chemically mediated organ of information that we carry in our skull; but unless this yield from the bench is clearly and continuously related to the uniquely human events that are the business of psychiatry and of neuropsychology, the implications of such knowledge must, of necessity, remain conjectural. All this is pretty obvious nowadays. In those days, however, in a Department of Pharmacology in Birmingham, it became part of a plan. I felt instinctively that the drugs we were working with, and drugs still to come, could be tools of great precision and power, depending (if one was lucky) on one or two overriding properties. It is this kind of precision pharmacology of the central nervous system that made me hopeful, and made me take up my stance in the face of raised eyebrows, which I encountered not only in the Physiological Society but also in psychiatric circles, where I was regarded as a maverick, newcomer, and a curiosity.

At that time, then, there were two anchoring points for our work in the mental disease field: neurochemistry, at the bench level, and human behavior, as influenced by drugs. There was nothing in between, no indicator that could relate the effects of drugs on the brain in the conscious animal to behavior, nor any correlation between behavior and chemistry of the brain. I began to hunt again. The EEG was at that time coming into its own. Hill and Pond (Hill 1944; Hill and Pond 1952) were publishing on the dysrhythmias, and Grey Walter (Walter and Walter 1949) and Gastaut (1950) were, in their own idiom, trying to relate functional states in man to EEG activity. And across the water there beckoned the great papers of Herbert Jasper (1949) and Wilder Penfield (1947). I plumbed for the effect of drugs on the electrical activity of the brain in the conscious animal. There were very few data available in those days except, a little later, those of Abraham Wikler (1952) and James Toman's review (Toman and Davis 1949). I obviously could not do it alone, and again I was in the market for an associate.

I cannot recall now who told Philip Bradley about me or me about Philip Bradley, but I remember clearly his coming to my office and telling me of his experience and his interests. He had been trained in zoology and had carried out microelectrode studies in insects. $\mathrm{He}$ seemed interested in the problem, and a salary was available. So, after some consultation with Dr. Grey Walter, arrangements were made for him to spend some time with Grey Walter, to learn EEG techniques and then set up his own laboratory in the second of the two rooms of "Mental Diseases Research." This was duly done; and in 1948, Philip was working alongside, developing his pioneering technique for recording the electrical activity in the conscious animal (Bradley 1953), a procedure that in those days (the days of sulfonamide-not penicillin), was quite a trick. The work proceeded well and quickly established reference points for a pharmacology of the brain, inasmuch as it relates to behavior. I still treasure a copy of Philip's thesis completed in October 1952 (Bradley 1952). It was a joy to see the clear and unambiguous effects of physostigmine, atropine, hyoscyamine, and amphetamine (and later, LSD-25) on the electrical activity of the brain in relation to behavior (Bradley and Elkes 1953, 1957). It 
was also particularly satisfying to find how these drugs grouped themselves in terms of their dependence on midbrain structures, and how information arriving at that time from Moruzzi and Magoun's studies (1949) could be related to our own findings. There gradually emerged (and this was my own view) a concept of the presence of families of compounds that had arisen in the brain, in the course of chemical evolution, and that were chemically related to powerful neurohumoral transmitters familiar to us at the periphery (Elkes 1953, $1958,1961)$. Three types of receptors, centering around members of the cholinester, the catecholamine and, later, the indole family, were proposed. Implicit in this concept of families of compounds was the concept of small, local, regional chemical fields; and of the interaction and interdependence between molecules governing and modulating the gating, storage, and flow in selfexciting neural loops. Reciprocal inhibition was regarded as the agent of structure in the central nervous system. I have modified these ideas somewhat since, and expressed them in various papers (Elkes 1953, 1958, 1961, 1966, 1967), but the concept of families of compounds, derived and evolved from respective common chemical root, governing the physiology of the brain (and, by implication, the chemistry of awareness, perception, affect, and memory) was a steady part of my thinking as we worked away in Birmingham; and to the best of my knowledge, represents an early formulation of these ideas. It gives me special satisfaction to reflect on Philip Bradley's subsequent illustrious career and the influence he has exerted on the course of neuropsychopharmacology in Europe and the world. He has now retired from the chairmanship of pharmacology in Birmingham.

As we wrote at the time (Bradley and Elkes 1957, pp. 113-114):

Perhaps rather than thinking in unitary terms, it may at this stage, be advisable to think in terms of the possible selection by chemical evolution of small families of closely related compounds, which by mutual interplay would govern the phenomena of excitation and inhibition in the central nervous system. Acetylcholine, nor-adrenaline and 5-hydroxytryptamine may be parent molecules of this kind; but one has only to compare the effects of acetylcholine with succinylcholine, or nor-adrenaline with its methylated congener to realize how profound the effects of even slight changes of molecular configuration can be. The astonishing use which chemical evolution has made of the steroids is but another example of the same economy. It is likely that neurons possessing slight but definite differences in enzyme constitution may be differentially susceptible to neurohumoral agents. Such neurons may be unevenly distributed in topographically close, or widely separated areas in the central nervous system; these differences probably extending to the finest level of histological organization. Phylogenetically older parts, and perhaps, more particularly, the mid-line

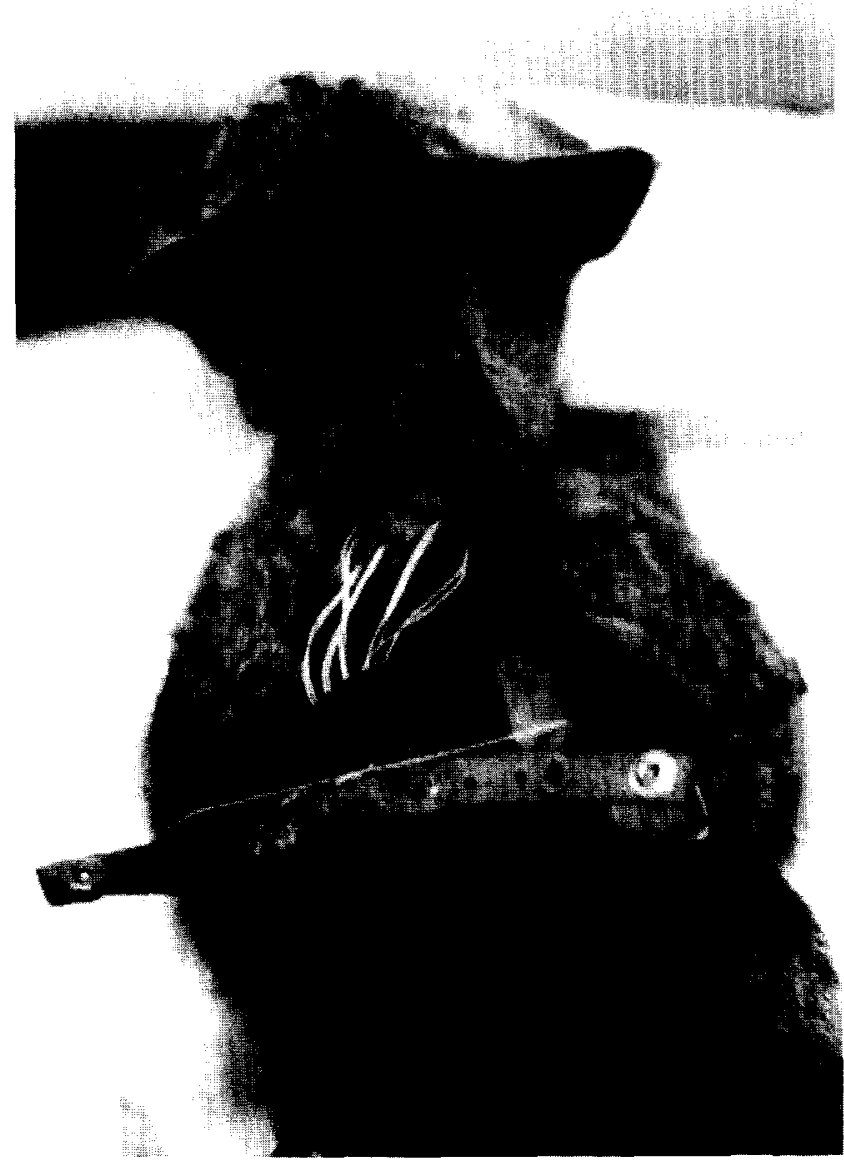

Figure 1. Leads of implanted electrodes emerging through skin leading to plug held in special harness. Reproduced by kind permission of P.B. Bradley from his thesis, 1952.

regions and the periventricular nuclei may, in terms of cell population and chemical constitution be significantly different from parts characteristic of late development. . . . It would perhaps be permissible to speak of the operation of chemical fields in these regions, which would depend on the rate of liberation, diffusion and destruction of locally-produced neurohumoral agents. The agents in question may be either identical with or, more likely, derived from neuro-effector substances familiar to us at the periphery. Their number is probably small, but their influence upon integrative action of higher nervous activity may be profound. The basic states of consciousness may well be determined by variations in the local concentration of these agents.

Bradley and I reported on the effects of amphetamine and LSD-25 at the January 1953 meeting of the Physiological Society (Bradley and Elkes 1953), and at the April 1953 meeting, Gaddum reported in now classic observation of the antagonism of LSD- 25 and serotonin (1953). All our experimental facts became relevant in proposing later that the LSD-sensitive receptor might be peculiarly related to the afferent system (possibly to 


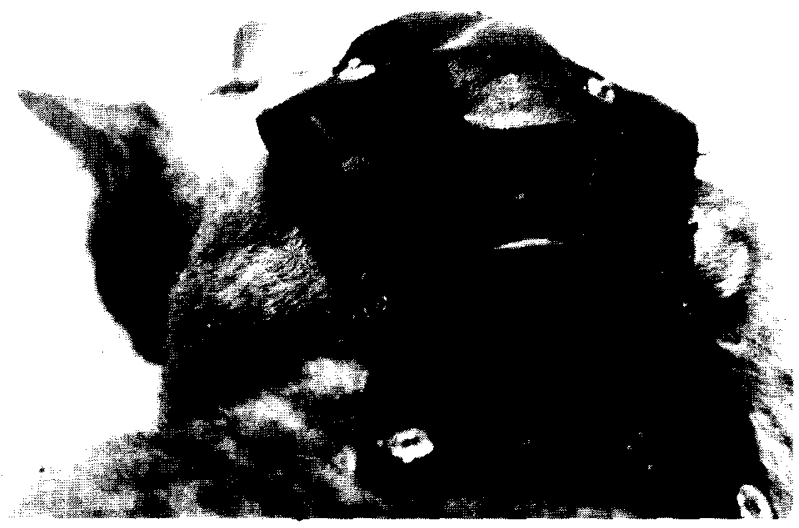

Figure 2. Plug carried by cat in harness, back view: protective flap open. Reproduced by kind permission of P.B. Bradley from his thesis, 1952.

the medial afferent collaterals) and exercise a selective inhibitory role in the organization of sensory information (Elkes 1958), a proposal not out of keeping with Aghajanian's more recent findings on the effects of LSD on the Raphe' nuclei (1970). Thus, in Birmingham we were developing a small experimental and clinical base for the study of the effects of drugs on brain and behavior. As mentioned earlier, we were impressed by the paradoxical effects of amytal, amphetamine, and mephenesin in catatonic schizophrenic stupor. We were also taken with the findings of Hill and Pond (Hill 1944; Hill and Pond 1952) and others suggesting temporal lobe dysfunction in aggressive antisocial states and possibly in schizophrenia. We were wondering whether the so-called antiepileptic drugs had a place in the treatment of these disorders. However, we did not know what awaited us. For one day there walked into my office Dr. W.R. Thrower, Clinical Director of Messrs.

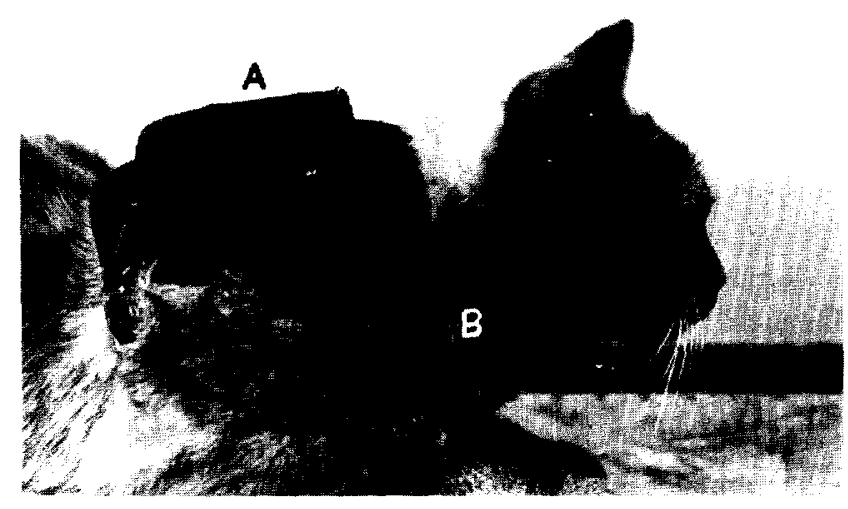

Figure 3. Plug carried by cat in harness, side view. A, protective flap, closed when in use; $B$, cross straps with press studs that can be released for periodic inspection of the skin. Reproduced by kind permission of P.B. Bradley from his thesis, 1952.

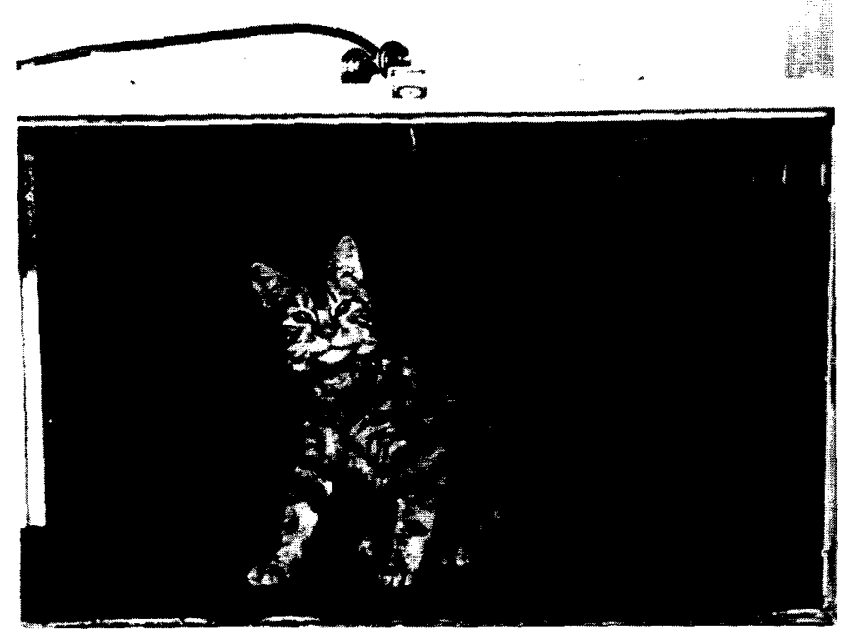

Figure 4. Observation chamber, front open, cat "plugged in": The lead moves freely on bicycle hub bearings. The rim of the stroboscope lamp can be seen on left. Reproduced by kind permission of P.B. Bradley from his thesis, 1952.

May and Baker. He said it was not a routine visit. He showed me, in English translation, the findings of Delay and Deniker concerning chlorpromazine (1953), findings that have been so admirably reviewed by Dr.

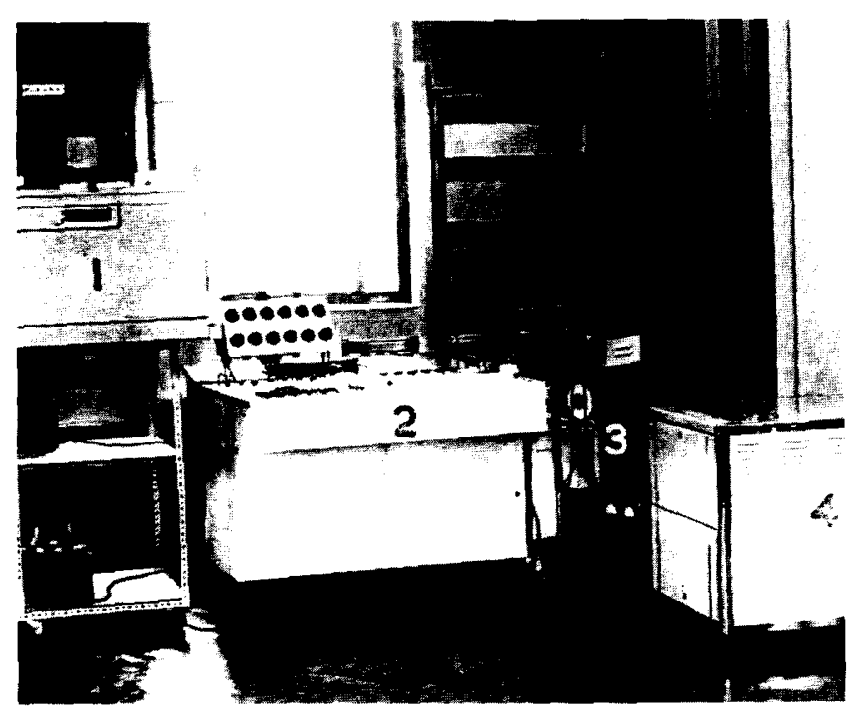

Figure 5. Arrangement for recording the effects of drugs on the electrical activity of the brain in the conscious cat. (Birmingham, England, 1948 onward): (1) constant environment chamber (underneath: stroboscope unit, and accumulators for D.C. supplies); (2) six channel electroencephotograph with electrode selector mounted on top; (3) rack carrying trigger unit for stroboscope control and test equipment; (4) wave analyzer. Reproduced by kind permission of P.B. Bradley from his thesis, 1952. 
Frank Ayd (1991). Dr. Thrower told me that May and Baker had acquired the British rights for chlorpromazine. They had a supply and could make up the necessary tablets. Would we care to perform a blind-controlled trial? Being very impressed by Delay and Deniker's reports, I said we certainly would and suggested that we could so so at Winson Green Mental Hospital. I asked Charmian whether she would be interested. She was, and it was she who assumed full responsibility for the management of what was to prove, I think, a rather important step in clinical psychopharmacology. For, as I think back on it, all the difficulties, all the opportunities, all the unpredictable qualities of conducting a trial in a mental hospital were to show up clearly, and to be dealt with clearly, in that early trial: the preparation of the ward, the training of personnel, the gullibility of us all (the so-called "halo" effect), the importance of nursing attendants, relatives, and patients themselves as informants; the use of rating scales and the calibration of such scales - all these elements came into their own, once Charmian (and to a lesser extent I) were faced with the realities of working in a "chronic" mental hospital ward. I still remember the morning when we all trooped into the board room of the hospital, spread the data on the large oak table, and broke the code after the ratings and side effects had been tabulated. The trial involved 27 patients chosen for gross agitation, overactivity, and psychotic behavior: 11 were affective, 13 schizophrenic, and 3 senile. The design was blind and self-controlled, the drug and placebo being alternated 3 times at six-week intervals. The dose was relatively low ( 250 to $300 \mathrm{mg}$ per day). We kept a criteria of improvement conservative, which was reflected in our discussion. Yet there was no doubt of the results: 7 patients showed marked improvement; 11 slight improvement; there was no effect in 9 patients. Side effects were observed in 10 patients. Our short paper, which conclusively proved the value of chlorpromazine (Elkes and Elkes 1954), and was the subject of an editorial in The British Medical Journal, was a blind self-controlled trial. But it was more; for it was a statement of the opportunities offered by a mental hospital for work of this kind, the difficulties one was likely to encounter, and the rules that one had to observe to obtain results. As we wrote (Elkes and Elkes 1954, p. 573):

Perhaps we may be allowed to draw attention to one last point-namely, the lessons we feel we have learned from the trial itself. The research instrument in a trial of this sort being a group of people, and its conduct being inseparable from the individual use of words, we were impressed by the necessity for a "blind" and self-controlled design and independent multiple documentation. Furthermore, we were equally impressed by the false picture apt to be conveyed if undue reliance was placed on interview alone, as conducted in the clinic room. The patients' behavior in the ward was apt to be very different.
For that reason the day and night nursing staff became indispensable and valued members of the observers' team. We were warmed and encouraged by the energy and care with which they did what was requested of them, provided this was clearly and simply set out at the beginning. A chronic "back" ward thus became a rather interesting place to work in. There may well be a case for training senior nursing staff in elementary research method and in medical documentation. This would make for increased interest, increased attention to, and respect for detail, and the availability of a fund of information, all too often lost because it has not been asked for.

The trial took place in a department, which by that time (1951) I had been invited to found. My dean, Sir Leonard Parsons, gave me the courage to begin, and his successor, Sir Arthur Thomson, continued with steadfast support. We called the new department, the Department of Experimental Psychiatry. I believe it was the first department of its kind anywhere. I chose the name deliberately to emphasize the research objectives of our enterprise. As indicated, the laboratory facilities were already available and had grown out of our previous work. But, as mentioned earlier, psychiatry, even experimental psychiatry, is clinical or it is nothing. Thus, quite early, we decided on the need for a clinical arm. The neurophysiology and neurochemistry laboratories were situated in the school of medicine and in a small new building provided by the Hospital Board (we were already working at the City Mental Hospital). What was needed was an Early Treatment Center, comprising inpatient and outpatient facilities. Again, we were fortunate. Through Dr. J.J. O'Reilly intervention, a mansion that had been previously the home of the Cadbury Chocolate Family became available. The name of the house was "Uffculme" and the name of our Clinic thus became the "Uffculme Clinic." Standing in its own lovely grounds, it comprised 42 beds, a day hospital, and an outpatient clinic. William Mayer-Gross joined us as Principal Clinical Associate in 1954, and John Harrington became Director of the Clinic in 1957. There were also biochemical laboratories, and an Ethology Laboratory to accommodate the work of Dr. M.R.A. Chance, I believe the first animal ethology laboratory in a psychiatric clinic.

We developed and maintained many productive and encouraging contacts. I still remember vividly $\mathrm{Hy}$ Denber's first visit to us soon after the publication of our chlorpromazine paper and our discussion on dosage levels. We had used $250 \mathrm{mg}$ with marked effects; across the water dosages had been much higher. There was exciting correspondence between Nate Kline (whom I had first met in 1950) and ourselves concerning reserpine. The Killams came, and a lifelong friendship ensued; and Jim Hance, who had worked with Phil Bradley, subsequently went to work with the Killams. Warren McCulloch and Pitts visited and fascinated our 


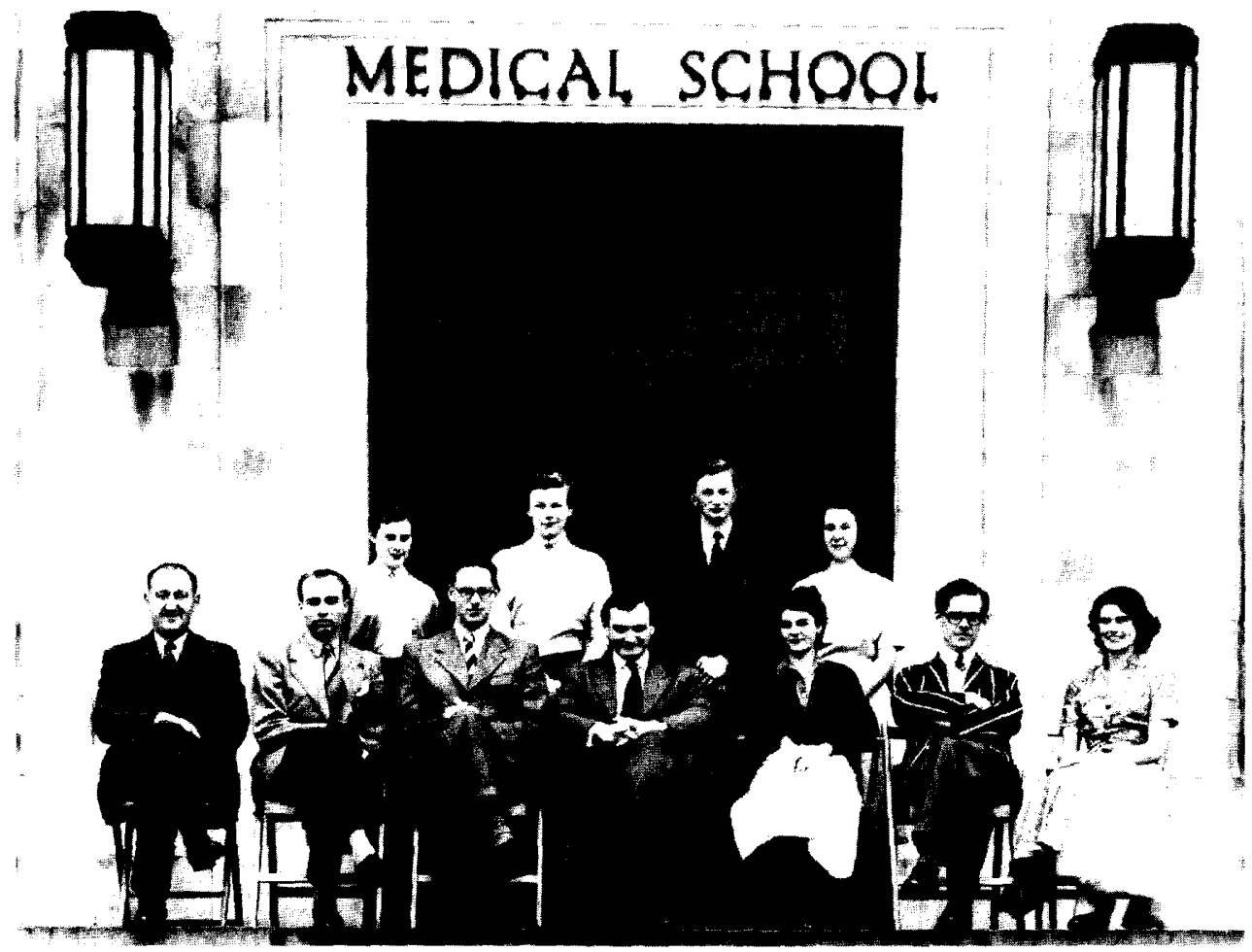

Figure 6. The Department of Experimental Psychiatry, University of Birmingham, Birmingham, England, 1953. Front row: (from left) A. Todrick, M. Piercy, P.B. Bradley, J. Elkes, C. Elkes, A. Baker, and L. Allan; back row: (technical colleagues) second from left, B. Bayliss; third from left, E. Bailey.

group by their mathematical models of self-regulation. Tinbergen (since, a Nobel Laureate) spoke at the Uffculme Clinic on ethology, and Leonard Cook, a most welcome visitor from S.K.F., shared with us some of the new and exciting techniques in the emerging field of behavioral neuropharmacology that he was developing. There were contacts with Ed Fellows (who had introduced "dexamyl"), with David Rioch and Joseph Brady at the Walter Reed, and later with Jim Olds. It was a tribute to the foresight of the Macy Foundation that they organized the splendid Macy Conferences on Neuropharmacology that brought us all together regularly.

In 1953, Hudson Hoagland organized an important interdisciplinary symposium at the Battelle Institute, at which we began to talk of social setting in relation to drug effects - sociopharmacology - a new and strange concept to the orthodox pharmacologist. The Rothlins spent three days as our guests in Birmingham, at which time, with Willy Mayer Gross and Philip Bradley, we began to talk about the need for a new journal, and possibly an international college. We were glad to learn that Springer, the publishers, were interested. Further discussions involved R. Jung (of Munich), J. Delay, P. Deniker, and P. Pichot (of Paris) and most importantly, Abraham Wikler (of Lexington). Perhaps this is the point to emphasize the prescient vision of psychopharmacology that Abe Wikler had developed at the time. His work on dependence and addiction was a model of rigor and clarity, but from the vantage point of some- one working both at the bench and in the clinic, he saw, long before most of us, the true dimensions of our field. He defined this beautifully in his book, The Relation of Psychiatry to Pharmacology (1957), now out of print. We were glad that we managed to persuade him to assume the coeditorship of Psychopharmacologia. I still remember the excitement when the first, slim, yellow-cover issue of Psychopharmacologia landed on my desk.

After my departure for the United States in 1957, our department was divided into a Department of Experimental Neuropharmacology, under Professor Philip Bradley, and a Clinical Department of Psychiatry, under Professor William (now Sir William) Trethowan, later Dean of the Medical Faculty. I am glad to say that until recently Uffculme Clinic was functioning very well as a postgraduate teaching center of the Birmingham Regional Hospital. Now there stands, on university grounds, the brand new Queen Elizabeth Psychiatric Hospital, the inauguration ceremonies of which I had the immense pleasure of attending last year.

\section{NEUROPHARMACOLOGY AND PSYCHOPHARMACOLOGY IN WASHINGTON, D.C., AND AT JOHNS HOPKINS, BALTIMORE}

As I mentioned earlier, I had spent a year (1950 to 1951) in the United States, having had the good fortune, through the offices of Ted Wallace of S.K.F., to be 
awarded the first Smith, Kline, and French Traveling Fellowship in England, and to get a Fulbright Award. I had a stimulating time at the late Samuel Wortis' Institute at New York University, also visiting Fritz Redlich's Institute at Yale, and also worked very productively at the Pratt (New England) Diagnostic Center at Boston with John Nemiah, later Editor-in-Chief of the American Journal of Psychiatry, who taught me much. Once again, the mental hospital exerted its pull. When I met with Dr. Redlich, I asked him whether it would not be advisable for me to get to know an American state hospital at first hand. It was duly arranged that I should spend five months at Norwich State Hospital, Connecticut. This was done through the courtesy of the late Dr. Kettle, Superintendent of the Hospital, a wonderful person to work with, and for. At that time, too, we discussed the question of building a research center at Norwich State Hospital, and some 10 years later that I got a joyous letter from Dr. Kettle that he had obtained funds tc create such a Center, which now is the Abraham Ribicoff Center for Mental Health Research at Norwich State Hospital.

It is during that time too, that I met Danny Freedman for the first time. To this day, I remember his comment at a seminar I gave concerning the possible relation of upper brain stem chemistry to schizophrenia. We saw alike and continued our exchanges later, distance notwithstanding. However, one of the most decisive meetings of my life was still to come. Before returning from the United States to England, I asked my friends at S.K.F. to arrange a visit with Seymour Kety, whose fundamental work on cerebral circulation I had admired from a distance for some years. This was duly done and one morning in the summer of 1951, I was in his laboratory at the University of Pennsylvania. We started talking and went on talking through a four-hour lunch. Seymour told me that he had just been appointed Scientific Director of the Intramural Program at NIMH, and I shared with Seymour that I was going back to England to occupy the newly created Chair of Experimental Psychiatry in the University of Birmingham. We talked of the possibilities of biological research in psychiatry and the exciting methods for in vivo work in man, which were just emerging. On a more personal level, a link was forged that day that has remained one of the most precious constants of my life.

Indeed, it is strange to reflect how constant are such constants. For when, in 1957, I received an invitation from Drs. Robert Cohen and Seymour Kety to create the Clinical Neuropharmacology Research Center at $\mathrm{NIMH}$, we all felt that biological research would gain by being in a realistic mental hospital setting. The hospital under consideration was St. Elizabeth's in Washington, D.C. Dr. Winfred Overholser, the superintendent, was duly approached and was very receptive. With Robert Felix's strong and continuous support, and with the exceptional understanding and enthusiasm of Drs. Bob Cohen and Seymour Kety, we established the Center at the William A. White building of the hospital. I will not hide the fact that it was hard going at first. We started, in 1957, with a secretary (Mrs. Anne Gibson) and myself in a large, dark, "Continued Care" building accommodating some 300 patients. However, time, energy, persistence, and support prevailed, and it became a research institute within two years. Again, the plan was the same: laboratories below, clinic above, and patients all around. The facilities grew and grew. Colleagues joined: Drs. Floyd Bloom, R. Byck, Richard Chase, R. Gjessing, R. Gumnit, Max Hamilton, Eliot Hearst, Tony Hordern, Shepherd Kellam, Don Lipsitt, T. Lofft, Richard Michael, Herbert Posner, G.C. Salmoiraghi, S. Szara, R. von Baumgarten, Neil Waldrop, Hans Weil-Malherbe, Harold Weiner, Paul Wender, R. Whalen, and many others. In 1961, Fritz Freyhan arrived as the Center's Director of Clinical Studies.

Again, some of the same themes (in variation) reappeared, though I cannot mention them all: microelectrophysiology, which, in Nino Salmoiraghi's hands mapped the pharmacology of respiratory neurons (1962) and later with Floyd Bloom, became a pioneering technique for the study of the pharmacology of individual neurons in the central nervous system (Salmoiraghi and Bloom 1964); amine metabolism, under H. Weil-Malherbe (Weil-Malherbe et al. 1962), which also initiated a collaboration with J. Axelrod (Axelrod et al. 1959), the metabolism of psychodysleptic tryptamine derivates, under Szara (Szara et al. 1962); animal behavioral studies, combining Skinnerian avoidance training with metabolic experiments under Eliot Hearst (Szara and Hearst 1962); the effect of locally and iso-
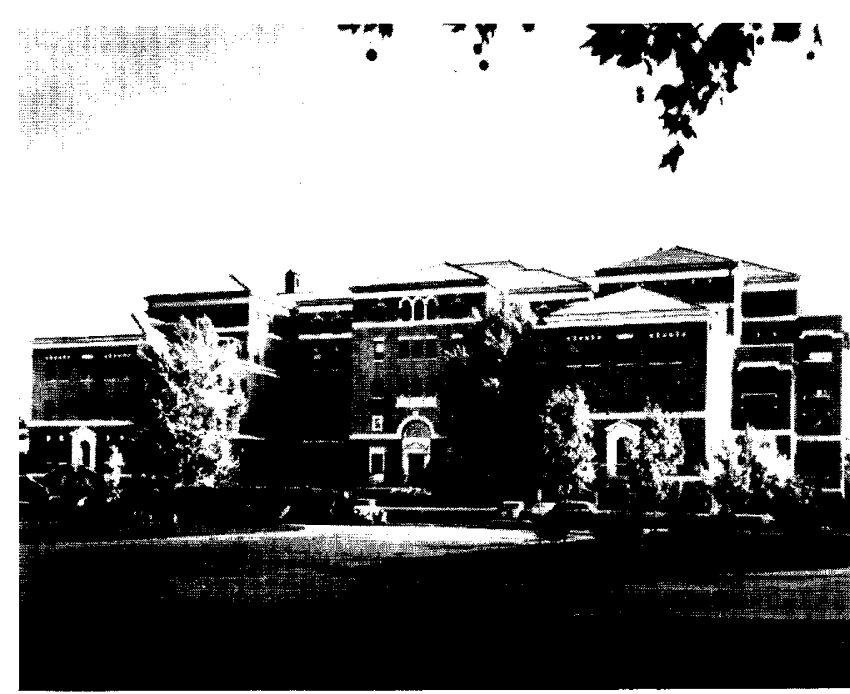

Figure 7. The William A. White Building, St. Elizabeth's Hospital, Washington, D.C. Site of the furst Clinical Neuropharmacology Research Center, NIMH, founded in 1957. Now site of The Neuroscience Center, NIMH. 
topically labeled implanted hormones on behavior, under Richard Michael (1961); human behavior analysis studies under Harold Weiner (1962); the methodology of clinical drug trials under Hordern and Lofft (Hordern et al. 1963), the quantification of social interaction in a psychiatric ward under Shepherd Kellam (1961); Max Hamilton, a visiting Fellow gave seminars on the methodology of Clinical Research, and the conceptualization of comprehensive mental health care in a given community by Fritz Freyhan (Freyhan and Mayo 1963); and studies on dependency, depression, and hospitalization by Don Lipsitt (1962). Later, with the help of the late Dr. Winfred Overholser, the Behavioral and Clinical Studies Center of St. Elizabeth's was created as a complementary entity, under the direction of Dr. Neil Waldrop.

Over the last two decades, the program-later the Division of Special Mental Health Programs of the National Institute of Mental Health - assumed dynamic leadership under Dr. G.C. Salmoiraghi and later, under Drs. Floyd Bloom and Ermino Costa, who, in their subsequent, remarkable careers, have made deep and lasting contributions to the neurosciences and psychopharmacology. The leadership of the program then passed into the very capable hands of Dr. Richard Wyatt, its well-known contribution continuing to this day.

In 1963, I was invited to assume the chairmanship of the Department of Psychiatry at Johns Hopkins, vacated the previous year by my friend, Seymour Kety. Here again, fate was kind. The University provided us with some new laboratories, and the old Phipps Clinic, still standing since Adolf Meyer opened it in 1913, provided room for some 80 patients and an outpatient clinic. I count myself most fortunate in the colleagues who were with us, in the residency and fellowship programs, and in major staff positions: Drs. Ross Baldessarini, Joseph Brady, Lino Covi, Joe Coyle, Len Derogatis, Louis Faillace, Jerome Frank, Arthur Freeman, Richard Hall, Nelson Hendler, John Money, Dennis Murphy, Candace Pert, Elliott Richelson, Solomon Snyder, Nahum Spinner, Joseph Stephens, Eberhard Uhlenhuth, Daniel van Kammen, Bill Webb, Herbert Weingartner, among others.

Three major developments began to take shape in my time: Dr. Solomon Snyder established his group in neuropharmacology, from a laboratory initially jointly supported by our department and the Department of Pharmacology. Dr. Paul Talalay, Chairman of Pharmacology and a true friend, showed a rare understanding for the emerging new field of psychopharmacology. It is a matter of deep joy and satisfaction to have watched Dr. Snyder's group grow to the world leadership position that it now occupies. He now holds the post of Distinguished Service Professor at Johns Hopkins and is head of the Department of Neurosciences, created for him in the university.
Dr. Joseph Brady, who joined us from Walter Reed, brought us another important component. As a clinical psychologist with a Skinnerian background, he developed behavior analysis and operant conditioning as a major research approach to the study of the effect of drugs on behavior. Bringing his great originality and boldness of approach into the clinical arena, he rapidly created at Johns Hopkins, the Division of Behavioral Biology and Behavioral Medicine, foreseeing clearly the shape of things to come. At the same time, Drs. Eberhard Uhlenhuth, Lino Covi, and later, Len Derogatis established much of the technology for quantitative trials in an outpatient setting. We also revived an old interest in the use of diphenylhydantoin in anxiety and depression (Dr. J. Stephens); and maintained contact with Drs. Al Kurland's and Stanislav Grof's group at the Maryland State Psychiatric Institute. It is good to know that research activities now continue vigorously in the new Adolf Meyer building under Dr. Paul $\mathrm{McHugh}$, and it warms the heart that we celebrated the 25th anniversary of our College under the leadership of "Uhli" Uhlenhuth, and that Joe Coyle is now leading psychiatry at Harvard.

\section{FOOTINGS OF A NEW SCIENCE: NEUROCHEMISTRY, ELECTROPHYSIOLOGY, ANIMAL BEHAVIOR AND THE CLINICAL TRIAL}

Looking back, with large national and international organizations in psychopharmacology spanning the globe, and vast industrial undertakings engaged in research, development, and manufacture, it is a little hard to visualize the sparse and intimate nature of our field some 40 years ago. As I said earlier, neurochemistry as we know, didn't really exist. And when I began, acetylcholine was still regarded as the principal chemical mediator in the central nervous system. Regional "elective affinities" of drugs for receptors remained in Henry Maudsley's memorable phrase, still to be "shadowed out" in the brain (Maudsley 1882), and Paul Ehrlich's "receptors" still an analogy. I remember sitting in Heinrich Waelsch's study overlooking the Hudson in August 1951, just before returning to England to take up my newly-created post. "What is experimental psychiatry?" asked Heinrich Waelsch, giving me that whimsical penetrating look of his. The newly named professor did not rightly know. "I suppose," I said, hesitatingly, "it is the application of experimental research method to clinical psychiatry; I suppose, in my own case, it is the application of chemistry to an analysis and understanding of behavior. I will tell you when I have done it for a while."

Later, back in England, I got in touch with Drs. Derek Richter and Geoffrey Harris; Heinrich Waelsch met with Drs. Seymour Kety, Jordi Folch-Pi, and Louis 
Flexner. Our joint hope, which we had shared at a previous small meeting, was to organize an International Neurochemical Symposium, the first of its kind. As the theme of the symposium, we significantly chose "The Biochemistry of the Developing Nervous System." As a place to hold it, we chose Magdalen College, Oxford. I was charged with being organizing Secretary, but could not have done it without the devoted help of my British colleagues. Sixty-nine colleagues from nine countries participated. It was a fine symposium. It may be that it was at this symposium that the term "neurochemistry" was used officially for the first time. The spirit of the meeting is conveyed in an extract from the Preface that Heinrich Waelsch and I wrote for the Proceedings (Waelsch and Heinrich 1955, p. 5):

\begin{abstract}
We agreed, also, that from the start it would be well to consider the brain as a biological entity in all its complexity of morphology and function, rather than as a homogenate, or an engineering problem. For that reason, we felt that the most useful contribution of a symposium of this kind would be an attempt to reintegrate biochemical process with structure and function, particularly with respect to the chemical topography of the brain, which, to us, seemed of greatest moment in an understanding of function. The program thus not only represents the framework of a conference, but also expresses an attitude; and of necessity includes discussion of structural, genetic, and pathological aspects, as well as subject matter that in the more limited sense may be termed "neurochemical." We feel that this approach may be helpful in slowly building the foundations for a rational therapy of disorders of the nervous system.
\end{abstract}

Three subsequent symposia reflected the momentum that was developing at this historic first meeting. The second on "The Metabolism of the Nervous System" was held in Aarhus, Denmark in 1956. The Proceed- ings were edited by D. Richter (1957). The third on "The Chemical Pathology of the Nervous System" followed in Strasbourg, France in 1958. The Proceedings were edited by Jordi Folch-Pi (1961). The Fourth International Symposium centered on "Regional Neurochemistry." It was held in Varenna, Italy in 1960. Seymour Kety and I edited the Proceedings (1961).

It is impossible to convey the excitement and productivity that attended these meetings as they steadily shaped some basic concepts in our field. I can only mention a very few examples, perforce omitting others of equal merit, referring the reader to the respective Proceedings.

There were, for example, the remarkable studies of the chemistry of single neurons using $X$-ray microphotometry by Holger Hyden (1955) and the chemical micromethods of Oliver Lowry, making possible the mapping the layer-by-layer of enzyme distribution in the retina and Ammon's horn (1955); quantitative cytochemical studies by Al Pope (1955); the early work on the distribution of Cholinesterase by Koelle (1961); descriptions of the biochemical specificities of neurons by R.W. Sperry (1955); the classical cerebral circulation studies by Seymour Kety (1957) and Lou Sokoloff (1961); studies on the metabolic responses to electric stimulation by Paul Greengard and H. Mcllwain (1955); and the whole concept of metabolic pools by $\mathrm{H}$. Waelsch (1961).

There came, in quick succession, the classical reviews of the place and regional distribution of Acetylcholine by Feldberg (1957), Norepinephrine by von Euler (1957) and Marthe Vogt (1957); Serotonin by Udenfriend, Bogdanski and Weissbach (1957) covering the early work of Gaddum (1953), Wooley and Shaw (1954), and Brodie, Pletscher, and Shore (1955), in the history of this key mediator in the brain; of gamma

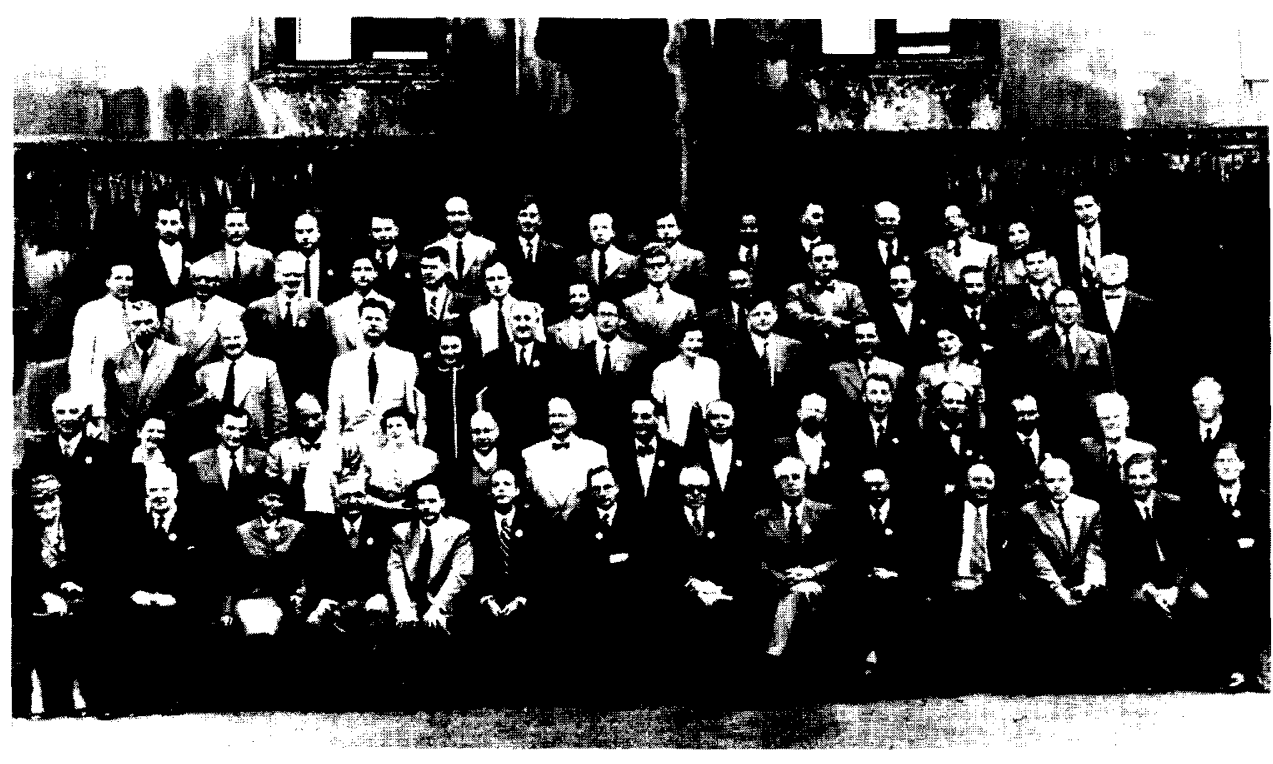

Figure 8. The First International Neurochemical Symposium held at Magdalen College, Oxford, 1954. 


\section{$11 / 12 / 83$}

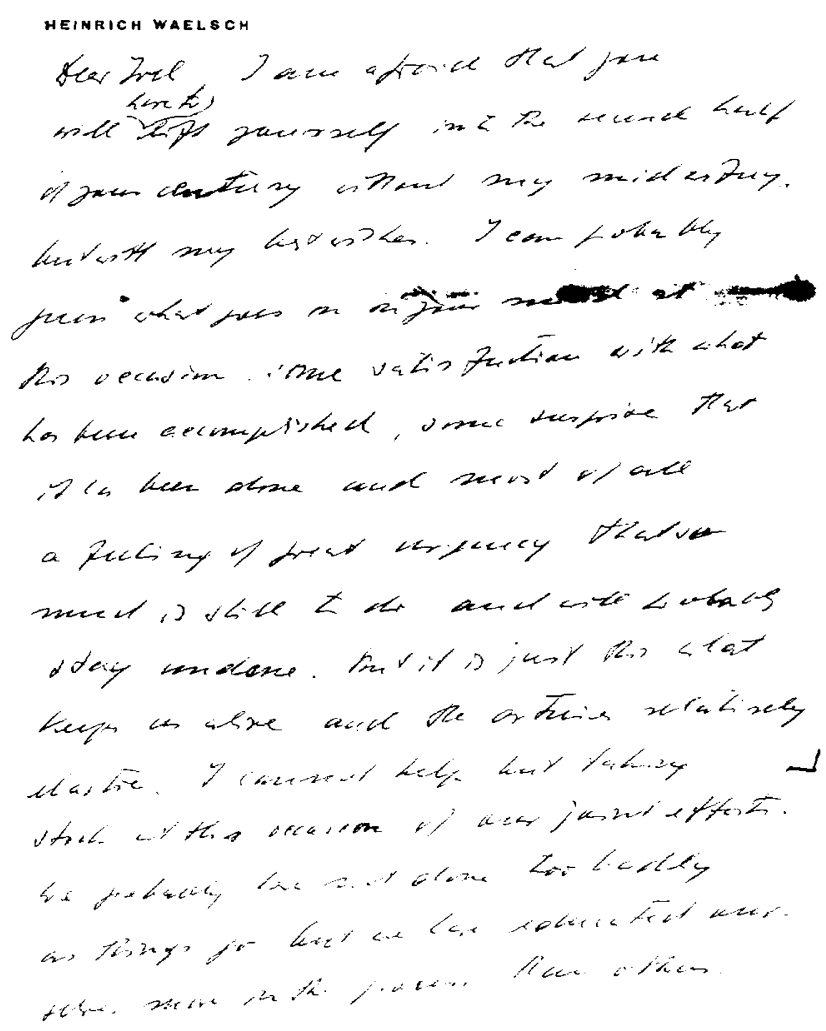

Figure 9. Letter written by Heinrich Waelsch, Professor of Neurochemistry, Columbia University, to Joel Elkes on the occasion of his 50th birthday (11/12/63). It reads: "I am afraid that you will have to lift yourself into the second half of your century without my midwifery but with my best wishes. 1 can probably guess what goes on in your mind at this occasion. Some satisfaction with what has been accomplished, some surprise that it has been done and most of all a feeling of great urgency that much is still to do, and will probably stay undone. But it is just this what keeps us alive, and the arteries relatively elastic. I cannot help but taking stock at this occasion of our joint efforts. We probably have not done too badly as things go, but we have educated ourselves more in the process than others."

butyric acid by Roberts (1961). An excellent early review on noncholinergic transmission (including Substance $P$, vasodilator substances, ATP, and histamine) was given by J. Crossland (1957). Most importantly, there was also the early presentation of the occurrence and effect of the nerve growth factor by Rita Levi Montalcini and P.U. Angeletti (1961). It is said that the highest compliment to a piece of work is its acceptance by the public to the point of anonymity of its authors. The names I mentioned are not exactly household words in psychopharmacology today; yet we owe some fundamental concepts of our science to them.
Similarly, in electrophysiology the early work on the sequential iontophoretic application of drugs and metabolites to single cells that started with the muscle end plate (Fatt 1954) and extended into the work of Curtis (1961) into the classical studies of Salmoiraghi and Bloom (1964), leading later to study of susceptibility to neurotransmitters in individual cells in mixed populations. These approaches complemented studies on the pharmacology of the reticular formation by the Killams (1956) and Bradley (1957), the effects of drugs on the electrical activity of the brain in the conscious animal mentioned above (Bradley and Elkes 1957), studies that quickly led to an analysis of the electrophysiological effects of Chlorpromazine (Bradley and Hance 1956).

Imagine, however, the excitement when these findings were put into the context of the effect of drugs on self-stimulation of the Reward systems in the hands of James Olds (1958) and the application of the Skinnearian approach to an analysis on the effects of drugs on behavior by Brady (1956) and Sidman (1956), and Dews (1955), the development soon thereafter of cognate approaches in the hands of many others too numerous to mention. In a word, as meetings proceeded, things began to connect: neurochemistry connected to electrophysiology, and electrophysiology to behavior: and animal behavior to the clinical trial. The difficulties in evaluation were faced early and honestly (Cole and Gerard, 1959 see below). Suddenly, an array of evaluation techniques was available. Industrial psychopharmacology took note and very rapidly moved our field mightily into the marketplace. Yet, our small group continued to do science by correspondence; I still remember the illegible notes, often on blue airmail letters (no fax in those days!), which brought the latest news. Those were heady days, to be sure. The process felt in some way like the collective painting of a mural; it all looked a bit weird at first, but month by month, and certainly year by year, it was beginning to make increasing sense: some pieces remained blurred, but others looked quite beautiful.

\section{THE EMERGENCE OF ORGANIZATIONS}

In the meantime, other important events were stirring. The Macy Symposia on Neuropharmacology, initiated by Dr. Harold Abramson in 1954, brought a number of us together (1954) and in 1956, under the joint chairmanship of Drs. Jonathan Cole and Ralph Gerard, a milestone Conference on Psychopharmacology was held under the aegis of the National Research Council, the National Academy of Sciences, and the American Psychiatric Association (1959), during which year also Dr. Cole's Psychopharmacology Service Center was created, a step of enormous consequence for the future development of the field all over the world. 


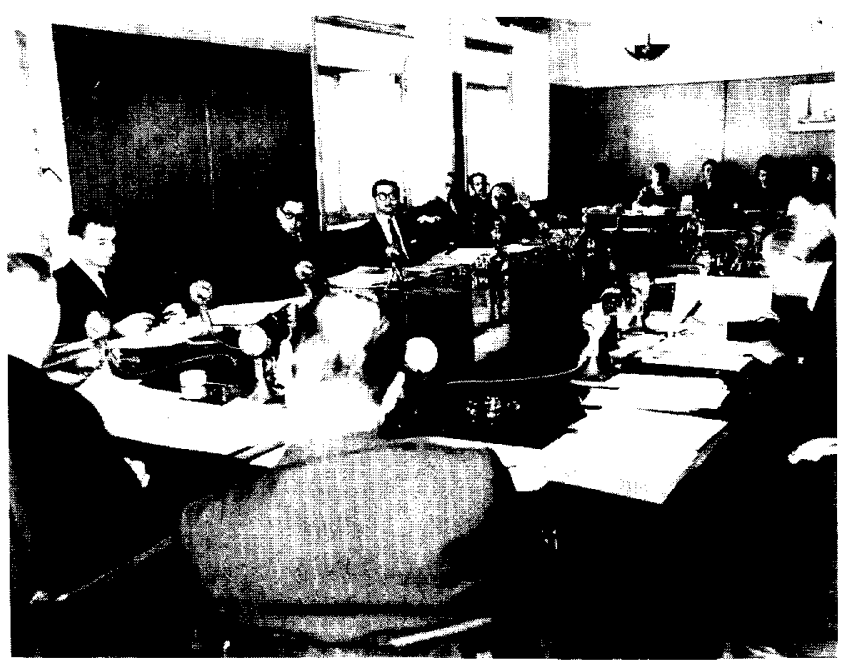

A

Wld Hith Org. techn. Rep. Ser., 1958, 152

WORLD HEALTH ORGANIZATION

TECHNICAL REPORT SERIES

No. 152

\section{ATARACTIC AND}

\section{HALLUCINOGENIC DRUGS}

\section{IN PSYCHIATRY}

\author{
Report of a Study Group
}
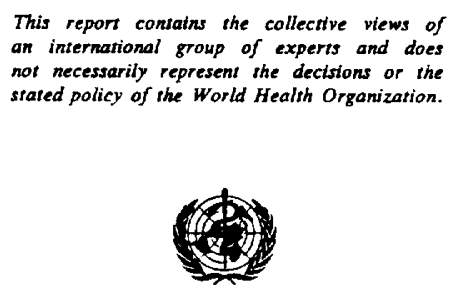

WORLD HEALTH ORGANIZATION

PALAS DES NATIONS

GENEVA

1958

\section{B}

Price : $3 / 6 \quad$ \$0.60 Sw. fr. 2.

Figure 10. (A) Meeting of the First World Health Organization Study Group on Ataractic and Hallucinogenic Agents, Geneva, 1957. In photo second from left: J. Elkes (USA, Chair); third from left: P.B. Schneider (Switzerland); fourth from left:
In 1957, the World Health Organization invited me to serve as consultant and convened a small study group on the subject of Ataractic and Hallucinogenic Drugs in Psychiatry. The following participated:

Ludwig von Bertalanffy, USA (Systems Theory) U.S. von Euler, Sweden (Pharmacology)

E. Jacobsen, Denmark (Pharmacology)

Morton Kramer, USA (Epidemiology)

T.A. Lambo, Nigeria (Transcultural Psychiatry)

E. Lindemann, USA (Psychiatry)

P. Pichot, France (Psychology)

D. McK. Rioch, USA (Neurosciences)

R.A. Sandison, England (Psychiatry)

P.B. Schneider, Switzerland (Clinical Pharmacology)

J. Elkes, England (Rapporteur)

I wrote the report (1958) which, incidentally, carried Eric Jacobsen's pioneer classification of the main drugs according to their pharmacological properties. In the meantime, the Scientific Command of the U.S. Air Force, through its principal representative in Europe, Col. James Henry, had catalyzed important work in the neurological sciences in a number of European laboratories. Through these meetings, the international implications of brain research became steadily more apparent. After preliminary meetings in 1958, 1959, and 1960, a number of us met in UNESCO House in 1960 to draft the statutes and bylaws of IBRO, the International Brain Research Organization. The disciplines of neuroanatomy, neurochemistry, neuroendocrinology, neuropharmacology, neurophysiology, behavioral sciences, neurocommunication, and biophysics were represented. Dr. Daniel Bovet and I represented neuropharmacology on the First Central Council of IBRO.

At about the same time, national groups in psychopharmacology began to form, at first loosely and informally, and later in more definitive ways. That most important international body, the Collegium Internationale Neuropsychopharmacologicum was born in 1956, and, as mentioned earlier - reflecting Drs. E. Rothlin's and Abraham Wikler's energy and devotion-our own journal of Psychopharmacologia, representing our new science, saw the light of day in 1959, and has continued as a yardstick of excellence since. In 1970, I had the great pleasure of founding the Israel Center for Psychobiology, a national center comprising representation from five universities and two research institutes. Psychopharmacology was richly represented in its

M. Kramer (USA); and middle right, in profile: E. Jacobsen (Denmark). Also (B) the title page of World Health Organization first Technical Report on psychoactive drugs (1958). Author Joel Elkes wrote this report. 


\section{American College of Neuropsychophaimacology}
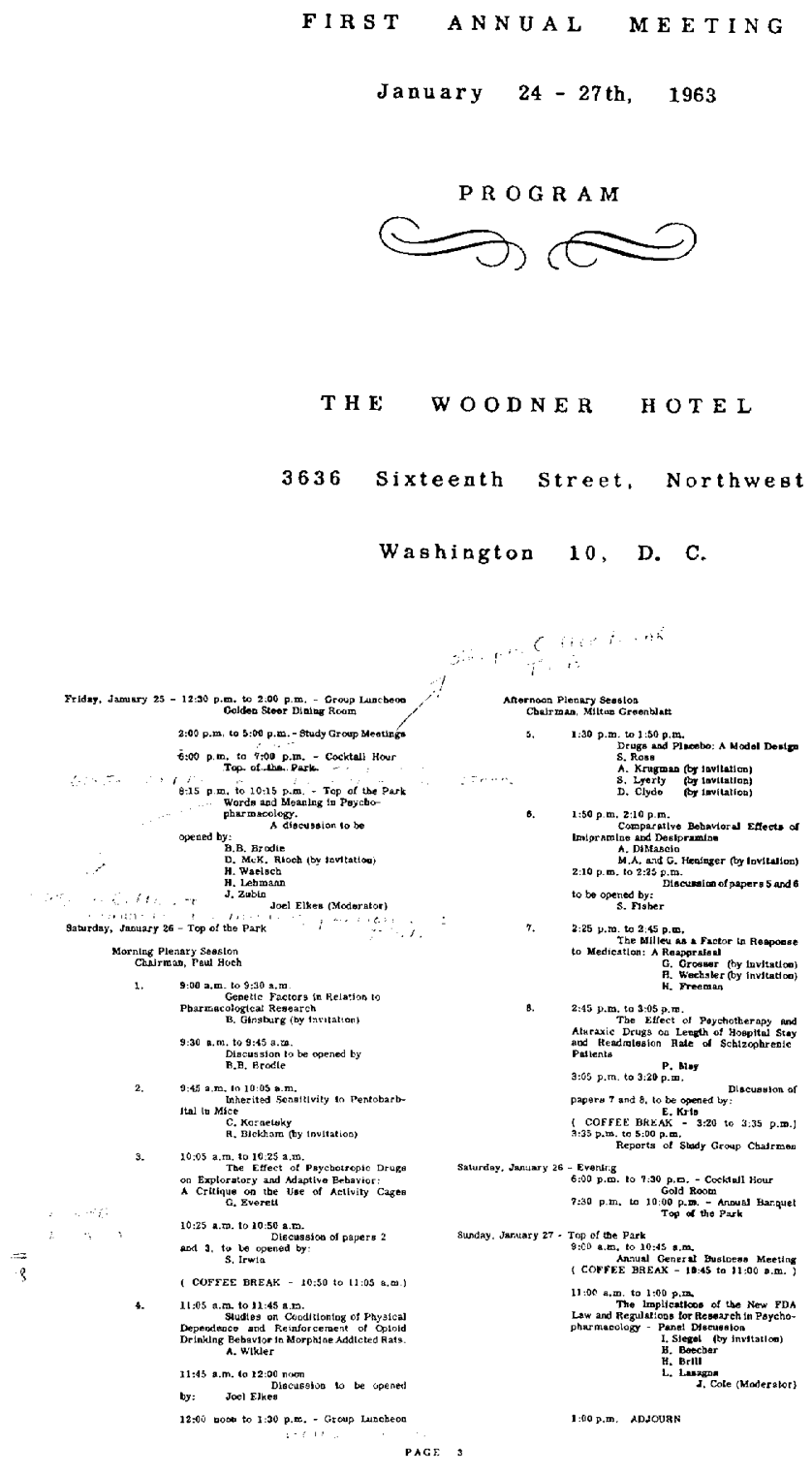

work. Drs. A. Carmon and M. Abeles succeeded me as Directors; and Dr. H. Belmaker, distinguished psychopharmacologist, has led the field in Israel since its inception. The Center is now known as the Israel National Institute for Psychobiology. I was also honored later, to be elected a Charter Fellow of the Canadian College of Neuropsychopharmacology.
Firgt anNual meeting

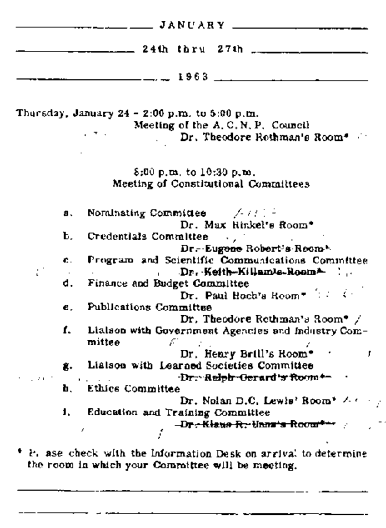

Friday. Jasuary 25 - 9.:00 a.m. to 9:18. A.te. Top of the Park

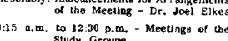

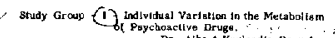

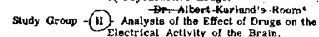

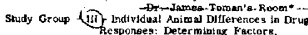

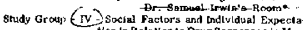

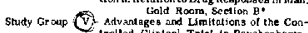

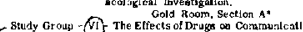

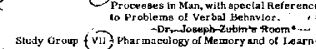

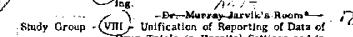
Strudy Group - (UIII) Unificitition of Reporthng of Data

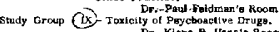
cor

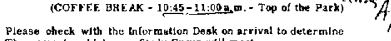

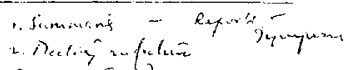

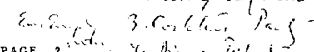
S.

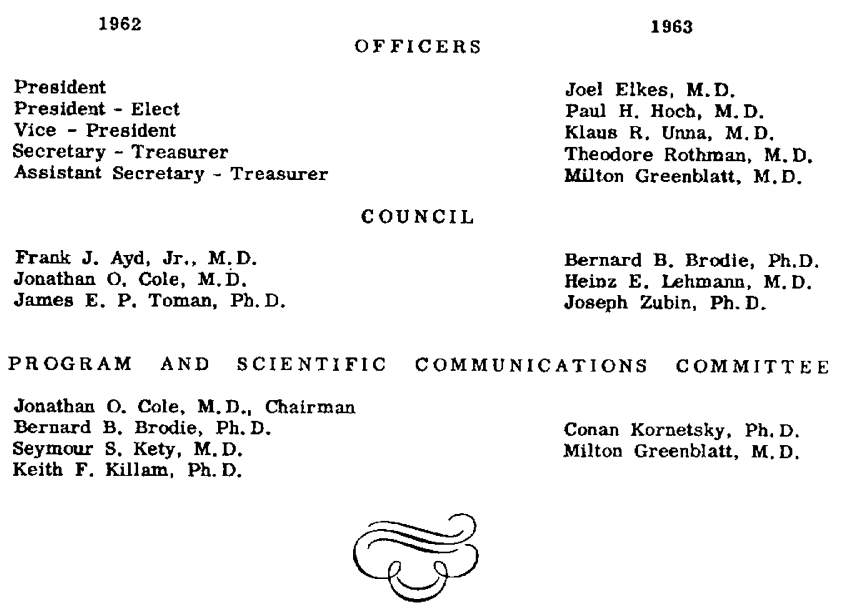

Figure 11. Pages from the program of the First Annual Meeting of the American College of Neuropsychopharmacology.

\section{CLOSING}

There are many other memories that flood the mind, but clearly these reminiscences have gone on much too long, and I must come to a close. When, through the initiatives of Drs. Ted Rothman, Paul Hoch, Jonathan Cole and some of us, as I have recorded elsewhere 
(1963), the American College of Neuropsychopharmacology was constituted in Washington in 1960, and you did me the immense honor of electing me your first President, I could not help remembering that this had happened only 15 years after I played with macromolecular models and the $x$-ray diffraction of myelin in my laboratory in Birmingham, and only 10 years after we had created a Department of Experimental Psychiatry in Birmingham. I could not help reflecting on the unique power of our field to act not only as a catalyst, but as a binder; a catalyst bringing into being whole new areas of science, but also as a binder and a relater of these sciences to each other. For we had not only to create fields of investigation and measuring devices in many disciplines, but also a degree of understanding and interaction between disciplines which is very rare. As I said at the time (1963):

It is not uncommon for any one of us to be told that Psychopharmacology is not a science, and that it would do well to emulate the precision of older and more established disciplines. Such statements betray a lack of understanding for the special demands made by Psychopharmacology upon the fields which compound it. For my own part, I draw comfort and firm conviction from the history of our subject and the history of our group. For I know of no other branch of science which, like a good plough on a spring day, has tilled as many areas in Neurobiology. To have, in a mere decade, questioned the concepts of synaptic transmission in the central nervous system; to have emphasized compartmentalization and regionalization of chemical process in the unit cell and in the brain; to have given us tools for the study of chemical basis of learning and temporary connection formation; to have emphasized the dependence of pharmacological response on its situational and social setting; to have compelled a hard look at the semantics of psychiatric diagnosis, description and communication; to have resuscitated that oldest of old remedies, the placebo response, for careful scrutiny; to have provided potential methods for the study of language in relation to the functional state of the brain; and to have encouraged the Biochemist, Physiologist, Psychologist, Clinician, the Mathematician and Communication Engineer to join forces at bench level, is no mean achievement for a young science. That a chemical text should carry the imprint of experience, and partake in its growth, in no way invalidates study of symbols, and the rules among symbols, which keep us going, changing, evolving and human. Thus, though moving cautiously, psychopharmacology is still protesting; yet, in so doing, it is, for the first time, compelling the physical and chemical sciences to look behavior in the face, and thus enriching both these sciences and behavior. If there be discomfiture in this encounter, it is hardly surprising; for it is in this discomfiture that there may well lie the germ of a new science.

In our branch of science, it would seem we are as attracted to soma as to symbol; we are as interested in overt behavior as we are aware of the subtleties of subjective experience. There is here no conflict between un- derstanding the way things are and the way people are, between the pursuit of science and the giving of service.

As new borderlands beckon, and as our science moves into fresh terrain, the chemical languages in which the nervous system, the endocrine system, and the immune system converse are becoming increasingly known. They are very precise. Receptors of common lineage suggest a remarkable economy in chemical evolution. Like a modern Rosetta Stone, psychopharmacology holds the key to much that is puzzling today. We must deepen our discourse with psychoimmunology, for we have much to offer to each other; and in a wider perspective, we may yet prove powerful brokers between quantum physics and the neurosciences. Concepts of electromagnetic fields (Adey 1988) may be needed to supplement our present concepts of chemical messaging: Who knows? The brain may emerge as a unique amplifier of very fast quantal events. As I delve into modern physics (Dyson, 1988), I continue to be reminded of the physics I read in my youth. When, in years to come, the chemical code is more fully read, new understanding will continue to astonish. There will be new approaches to healing, new hopes for many; and with it an ethical dilemma remorseless in its recurrent dialectic.

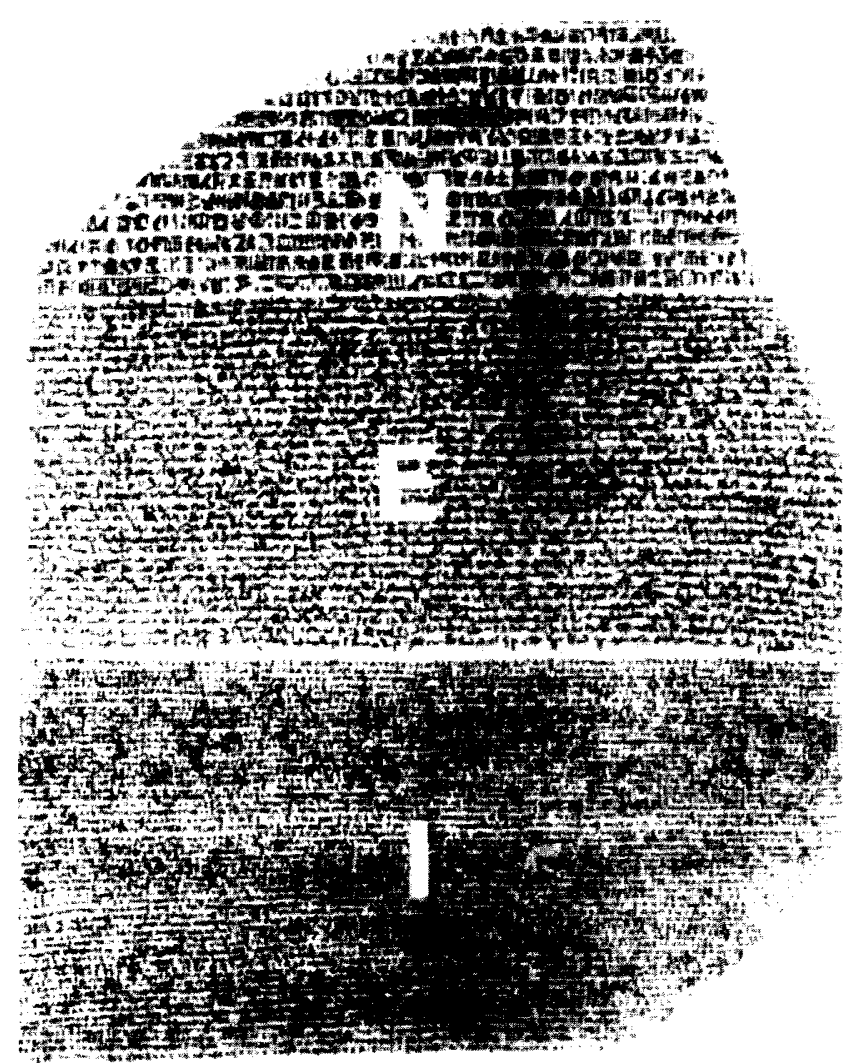

Figure 12. Like the Rosetta Stone, Psychopharmacology provides a key to three languages: the nervous system $(\mathrm{N})$; the endocrine system (E); and the immune system (I). 
Today, street drugs are a tragedy, and smart drugs still a joke: But when our college meets a quarter of century hence, huge new questions will loom, and will not go away. Let us, therefore, while there is still time, develop structures to guard us from the consequences of our own curiosity, and - dare I say it? - our own ambitions. I remember discussing such matters with Leo Szilard to whose seminal insights we owe the very origins of the atomic bomb. We met shortly before he died. You may recall that very early in the game, he and his colleagues created the "Bulletin of the Atomic Scientists." On the face sheet there was displayed a clock, the position of its hands reflecting the political stability of our world. At the time of the Cuban missile crisis, they read a few seconds to twelve; they may have shifted to a more reassuring position since. Perhaps we should think of our own bulletin, in which we could speak of our hopes, achievements, and fears to society. There is no greater safeguard against the consequences of our inventiveness than an informed public. As for our clock, and the ticking of what my wife, Josephine, calls the "Brain Bomb," I do not know what time the hands would show this fine morning in December 1992; but I suspect it may be later than we think.

\section{ACKNOWLEDGMENT}

The author wishes to express his sincere thanks to Professor P.B. Bradley, Professor Emeritus, University of Birmingham, England, for his kind permission to reproduce photographs from his thesis; to Dr. Frank J. Ayd for his permission to draw on an earlier paper given by the author at a meeting convened by Dr. Ayd in 1970 [Discoveries in Biological Psychiatry, F.J. Ayd and Barry Blackwell (editors) Lippincott, 1970]. He deeply appreciates the hospitality given him by the Fetzer Institute, Kalamazoo, Michigan, during the preparation of this article, and the expert technical assistance of Ms. Carolyn Dailey, Administrative Assistant at the Institute

\section{REFERENCES}

Adey WR (1988): Physiological signalling across cell membranes and cooperative influences of extremely low frequency electromagnetic fields. In Frohlich, H (ed), Biological Coherence and Response to External Stimuli. Springer-Verlag, pp 148-170

Abramson HA (ed) (1954): Neuropharmacology. New York, Josiah Macy Jr. Foundation

Aghajanian GK (1970): Effects of LSD on raphe nuclei neurons. Neurosciences Res Program Bull 8:40-54

Axelrod J, Weil Malherbe H, Tomchik R (1959): The physiological disposition of $\mathrm{H}(3)$ epinephrine and its metabolite metanephrine. J Pharmocol Exptl Therapeutics 127:251-256

Ayd FJ (1991): The early history of modern psychopharmacology. Neuropsychopharmacology 5:71-85

Berger FM, Bradley W (1946): The pharmacological prop- erties of $\chi: \beta$ dihydroxy- $\gamma$-(2-methylphenoxy)-propane (Myanesin). Brit J Pharmacol 1:265

Bradley PB (1952): Observations of the Effects of Drugs on The Electrical Activity of the Brain. Thesis, submitted as a candidate to qualify for the degree of Philosophae Doctor, University of Birmingham, England

Bradley PB (1953): A technique for recording the electrical activity of the brain in the conscious animal. Electroenceph Clin Neurophysiol 5:451

Bradley PB (1957): Microelectrode approach to the neuropharmacology of the reticular formation. In Garratini S, Ghetti V (eds), Psychotropic Drugs. Amsterdam, Elsevier, p 201

Bradley PB, Elkes J (1953): The effect of atrophine, hyoscyamine physostigmine and neostigmine on the electrical activity of the brain of the conscious cat. J Physiol (London) 120:14

Bradley PB, Elkes J (1957): The effects of some drugs on the electrical activity of the brain. Brain 80:77-117

Bradley PB, Elkes J (1953): The effect of amphetamine and d-lysergic acid diethylamide (LSD-25) on the electrical activity of the brain of the conscious cat. J Physiol (London) 120:13

Bradley PB, Hance AJ (1956): The effects of chlorpromazine and methopromazine of the electrical activity of the brain in the cat. EEG Clin Neurophysiol 6:191-215

Brady JV (1956): Assessment of drug effects on emotional behavior. Science 123:1033

Brodie BB, Pletscher A, Shore PA (1955): Evidence that Serotonin Has a Role in Brain Function. Science 122:968

Cole J, Gerard RW (eds) (1959): Psychopharmacology: Problems in Evaluation. Washington, DC, National Academy of Science and National Research Council

Crossland J (1957): The problem of non-cholinergic transmission in the central nervous system. In Richter D (ed), The Metabolism of the Nervous System, Oxford, Pergamon, pp 523-541

Curtis DR (1961): The effects of drugs and amino acids upon neurons. In Kety SS, Elkes J, (eds), Regional Neurochemistry, Oxford, Pergamon, pp 403-422

Delay J, Deniker P (1953): Les neuroplegiques en therapeutique psychiatrique. Therapie 8:347

Dews PB (1955): Studies on behavior. I. Differential sensitivity to pentobarbital of pecking performance in pigeons depending on schedule of reward. J Pharmacol Exp Therap 113:393

Dyson F (1988): Infinite in all directions: The Gifford Lectures. New York, Harper and Row

Elkes J (rapporteur) (1958): Ataractic and Hallucinogenic Drugs in Psychiatry. WHO Tech Rep Series, 152. Geneva, World Health Organization

Elkes J (1963): The American College of Neuropsychopharmacology: A note on its history and hopes for the future. Amer College Neuropsychopharmacology Bulletin 1:2-3

Elkes J (1957): Some effects of psychotomimetic drugs on the experimental animal and in man. In Neuropharmacology, Transactions of the Third Conference, New York, Josiah Macy, Jr. Foundation, pp 205-294

Elkes J (1953): In Tanner, JM (ed), Prospects in Psychiatric Research. Oxford (England), Blackwell, p 126 
Elkes J (1958): Drug effects in relation to receptor specificity within the brain: Some evidence and provisional formulation. In Wostenholme, G (ed), Ciba Foundation Symposium on the Neurological Basis of Behavior. London, Churchill, pp 303-332

Elkes J (1961): Drugs influencing affect and behavior: Possible neural correlates in relation to mode of action. In Simon A (ed), The Physiology of Emotions. Springfield (IL), Thomas, p 95

Elkes J (1966): Psychoactive drugs: Some problems and approaches. In Solomon P (ed), Psychiatric Drugs. New York, Grune, pp 4-21

Elkes J (1967): Behavioral pharmacology in relation to psychiatry. In Gruhle HW, Jung R, Mayer-Gross W, and Muller M (eds), Psychiatrie der Gegenwart, Berlin, Springer, pp 931-1038

Elkes J, Eayrs JT, Todrick A (1955): On the effect and the lack of effect of some drugs on postnatal development in the rat. In Waelsch $\mathrm{H}$ (ed), Biochemistry of the Developing Nervous System, New York, Academic, p 409

Elkes J, Elkes C (1954): Effects of chlorpromazine on the behaviour of chronically overactive psychotic patients. Brit Med J 2:560

Elkes J, Elkes C, Bradley PB (1954): The effect of some drugs on the electrical activity of the brain and on behavior. J Ment Sci 100:125

Elkes J, Finean JB (1949): The effect of drying upon the structure of myelin in the sciatic nerve of the frog. In Discussion of the Faraday Society (Lipoproteins), London, p 134

Elkes J, Finean JB (1953): X-ray diffraction studies on the effects of temperature on the structure of myelin in the sciatic nerve of the frog. Exp Cell Res 4:69

Elkes J, Finean JB (1953): Effects of solvents on the structure of myelin in the sciatic nerve of the frog. Exp Cell Res 4:82

Elkes J, Frazer AC, Stewart HC (1939): The composition of particles seen in normal human blood under dark ground illumination. J Physiol 95:68

Elkes J, Todrick A (1955): On the development of the cholinesterases in the rat brain. In Waelsch $\mathrm{H}$ (ed), Biochemistry of the Developing Nervous System. New York, Acad Press, p 309

Engstrom A, Finean JB (1958): Biological Ultrastructure. New York, Academic Press

Fatt P (1954): Biophysics of junctional transmission. Physiol Rev 34:674

Feldberg W (1957): Acetylcholine. In Richter, D (ed), The Metabolism of the Nervous System, Oxford, Pergamon, pp 493-510

Feldberg W, Vogt M (1948): Acetylcholine synthesis in different regions of central nervous system. J Physiol (London) $107: 372$

Finean JB (1961): Chemical Ultrastructure in Living Tissues. Springfield (IL), Thomas

Folch-Pi J (ed) (1961): The Chemical Pathology of the Nervous System, Proceedings of the Third International Symposium in Neurochemistry. Oxford, Pergamon

French AP (ed) (1979): Einstein: A centenary volume. Cambridge (MA), Harvard University Press

Freyhan F, Mayo JA (1963): Concept of a model psychiatric clinic. Amer J Psychiat 120:222

Gaddum JH (1953): Antagonism between lysergic acid diethylamide and 5-hydroxytryptamine. J Physiol (London) 121:15

Gastaut H (1950): Combined photic and metrazol activation of the brain. Electroenceph Clin Neurophysiol 2:263

Greengard P, Mcllwain H (1955): Metabolic response to electrical pulses in mammalian cerebral cortex during development. In Waelsch, H (ed), The Biochemistry of the Developing Nervous System, New York, Academic, pp 251-260

Himmelwait F (ed) (1956): The Collected Papers of Paul Ehrlich. London/New York, Pergamon

Himwich HE, Bowman KM, Fazekas JF, Goldfarb W (1940): Temperature and brain metabolism. Amer J Med Sci 200:347

Hill D (1944): Cerebral dysrhythmia: Its significance in aggressive behavior. Proc Roy Soc Med 37:317

Hill D, Pond DA (1952): Reflections of one hundred capital cases submitted to electroencephalography. J Ment Sci 98:23

Hordern A, Hamilton M, Waldrop FN, Lofft JC (1963): A controlled trial on the value of prochlorperazine and trifluoperazine and intensive group treatment. Brit J Psychiat 109:510-522

Hyden H (1955): The chemistry of single neurons; A study with new methods. In Waelsch $\mathrm{H}$ (ed), Biochemistry of the Developing Nervous System. New York, Academic, pp 359-371

Jasper H (1949): Symposium: Thalamocortical relationships; diffuse projection systems: Integrative action of thalamic reticular system. Electroenceph Clin Neurophysiol 1:406

Kellam SG (1961): A method for assessing social contact: Its application during a rehabilitation program on a psychiatric ward. J Nerv Ment Dis 132:277

Kety S, Elkes J (eds) (1961): Regional Neurochemistry, Proceedings of the Fourth International Symposium in Neurochemistry. Oxford, Pergamon

Kety SS (1957): General metabolism of the brain in vivo. In Richter D (ed), The Metabolism of the Nervous System, Oxford, Pergamon, pp 221-237

Killam KF, Killam EK (1956): A comparison of the effects of reserpine and chlorpromazine to those of barbituates on central afferent systems in the cat. J Pharmacol Exp Ther $116: 35$

Kluver H (1942): Mechanisms of hallucinations. In McNemar Q, Merrill MA (eds), Studies in Personality. New York, McGraw-Hill, p 175

Koelle GB (1961): Evidence for differences in primary functions of acetylcholinesterase at different synapses and neuroeffector junctions. In Kety S, Elkes J (eds), Regional Neurochemistry. Oxford, Pergamon, pp 312-323

Lehman H (1991): "Before they called it psychopharmacology" - invited ACNP lecture, presented at 30th Annual Meeting of the American College of Neuropsychopharmacology, San Juan, Puerto Rico, December 10th

Levi-Montalcini R, Angeletti PU (1961): Biological properties of a nerve growth promoting protein and its antiserum. In Kety SS, Elkes J (eds), Regional Neurochemistry, Oxford, Pergamon, pp 363-377

Lindemann E, Malamud W (1934): Experimental analysis of the psychopathological effects of intoxicating drugs. Amer J Psychiat 13:853 
Lipsitt DR (1962): Dependency, depression, and hospitalization: Towards an understanding of a conspiracy. Psychiatric Quarterly 30:537-554

Lowry OH (1955): A study of the nervous system with quantitative histochemical methods. In Waelsch $\mathrm{H}(\mathrm{ed})$, The Biochemistry of the Developing Nervous System, New York, Academic, pp 350-357

Masserman JH (1946): An analysis of the influence of alcohol on experimental neuroses in cats. Psychosom Med 8:36

Maudsley H (1882): The Physiology and Pathology of the Mind, Third Edition, Part 2. New York, Appleton, p 195

McDougall W (1935): The Frontiers of Psychology. Cambridge (England), Cambridge University Press

Michael RP (1961): An investigation of the sensitivity of circumscribed neurological areas to hormonal stimulation by means of the application of oestrogens directly to the brain of the cat. In Kety S, Elkes J (eds), Regional Neurochemistry. Oxford (England), Pergamon, p 465

Michaelis M, Quastel JH (1941): Site of action of narcotics in respiratory processes. Biochem J 35:518.

Moruzzi G, Magoun HW (1949): Brainstem reticular formation and activation of the EEG. Electroenceph Clin Neurophysiol 1:455

Nevinson HW (1931): Goethe: Man and Poet: Written for the Centenary of Goethe's Death. London (England), Nisbet

Olds J (1958): Selective effects of drives and drugs in "reward" systems of the brain. In Wostenholme G (ed), Ciba Symposium on Neurological Basis of Behavior. London, Churchill, p 124

Page IH (1937): Chemistry of the Brain. Springfield (IL), Thomas

Pauling L (1945): The Nature of the Chemical Bond and the Structure of Molecules and Crystals: An Introduction to Modern Structural Chemistry. Ithaca (NY), Cornell University

Penfield W (1947): Ferrier lecture: Some observations on the cerebral cortex of man. Proc Roy Soc Med 134:329

Pickworth FA (1941): Occurrence and significance of small vascular lesions in brain. J Men Sc 87:50-76

Pope A (1955): The relationship of neurochemistry to the microscopic anatomy of the nervous system. In Waelsch $\mathrm{H}$ (ed), Biochemistry of the Developing Nervous System, New York, Academic, pp 341-349

Richter D (1940): Inactivation of adrenaline in vivo in man. J Physiol (London) 98:361

Richter D (ed) (1957): The Metabolism of the Nervous System, Proceedings of the Second International Symposium in Neurochemistry. Oxford, Pergamon

Roberts E (1961): Metabolism of gamma amino butyric acid in various areas of the brain. In Kety SS, Elkes J (eds), Regional Neurochemistry, Oxford, Pergamon, pp 324339

Salmoiraghi GC (1962): Pharmacology of Respiratory Neurons, Proceedings of First International Pharmacology Meetings. Oxford, Pergamon, pp 217-229

Salmoiraghi GC, Bloom FE (1964): Pharmacology of individual neurons. Science 144:493

Sargant W, Shorvon HJ (1945): Acute war neuroses. Arch Neurol (Chicago) 54:231
Schmitt FO (1935): X-ray diffraction studies on nerve. Radiology 25:131

Schmitt FO (1941): X-ray diffraction studies on structure of nerve myelin sheath. J Cell Physiol 18:31

Sherrington CS (1911): The Integrative Action of the Nervous System. New Haven, Yale University Press

Sherrington CS (1941): Man on His Nature. Cambridge (England), Cambridge University Press, p 104

Sidman M (1956): Drug behavior interaction. Ann NY Acad Sc 65:282

Sokoloff L (1961): Local cerebral circulation at rest and during altered cerebral activity induced by anaesthesia or visual stimulation. In Kety S, Elkes J (eds), Regional Neurochemistry, Oxford, Pergamon, pp 107-117

Sperry RW (1955): Problems in the biochemical specification of neurons. In Waelsch $\mathrm{H}(\mathrm{ed})$, The Biochemistry of the Developing Nervous System, Oxford, Pergamon, pp 75-84

Szara S, Hearst E (1962): The 6-hydroxylation of tryptamine derivatives: A way of producing psychoactive metabolites. Ann NY Acad Sci 96:134

Szara S, Hearst E, Putney F (1962): Metabolism and behavioral action of psychotropic tryptamine homologues. Int J Neuropharmacol 1:111

Thudichum JWL (1884): A Treatise on the Chemical Constitution of the Brain. London, Balliere

Toman J, Davis JP (1949): The effects of drugs upon the electrical activity of the brain. Pharmacol Rev 1:425

Udenfriend S, Bogdanski DF, Weissbach H (1957): Biochemistry and metabolism of serotonin as it relates to the nervous system. In Richter D (ed), The Metabolism of the Nervous System, Pergamon, pp 567-577

Vogt M (1957): Distribution of adrenaline and noradrenaline in the central nervous system and its modification by drugs. In Richter D (ed), The Metabolism of the Nervous System, Pergamon, pp 553-565

Von Euler US (1957): Noradrenaline. In Richter D (ed), The Metabolism of the Nervous System, Pergamon, pp 543-552

Waelsch H (ed) (1955): Biochemistry of the Developing Nervous System, Proceedings of the First International Symposium in Neurochemistry. New York, Academic, p 5

Waelsch H (1961): Compartmentalized biosynthetic reactions in the central nervous system. In Kety SS, Elkes J (eds), Regional Neurochemistry, Oxford, Pergamon, pp 57-64

Walter VJ, Walter WG (1949): The central effects of rhythmic sensory stimulation. Electroenceph Clin Neurophysiol $1: 57$

Weil Malherbe H, Smith ERB (1962): Metabolites of catecholamines in urine and tissues. J Neuropsychiatry, pp 113-117

Weiner H (1962): Some effects of response cost upon human operant behavior. J Exp Anal Behav 5:201

Wikler A (1952): Pharmacologic dissociation of behavior and EEG "sleep patterns" in dogs; morphine, n-allylnormorphine and atropine. Proc Soc Exp Biol Med, 79:261

Wikler A (1957): The Relation of Psychiatry to Pharmacology Baltimore, Williams and Wilkins

Wooley DW, Shaw E (1954): A Biochemical and Pharmacological Suggestion about Certain Mental Disorders. Proc Nat Acad Sciences 40:228 